\title{
Article
}

\section{Read-Across of 90-day Rat Oral Repeated-Dose Toxicity: A Case Study for Selected n-Alkanols}

Schultz, T.W, Przybylak, K.P, Richarz, A-N, Mellor, Claire, Escher, S.E, Bradbury, S.P and Cronin, M.T.D

Available at http://clok.uclan.ac.uk/17638/

Schultz, T.W, Przybylak, K.P, Richarz, A-N, Mellor, Claire ORCID: 0000-00027647-2085, Escher, S.E, Bradbury, S.P and Cronin, M.T.D (2017) Read-Across of 90-day Rat Oral Repeated-Dose Toxicity: A Case Study for Selected nAlkanols. Computational Toxicology .

It is advisable to refer to the publisher's version if you intend to cite from the work. http://dx.doi.org/10.1016/j.comtox.2017.02.002

For more information about UCLan's research in this area go to http://www.uclan.ac.uk/researchgroups/ and search for <name of research Group>.

For information about Research generally at UCLan please go to http://www.uclan.ac.uk/research/

All outputs in CLoK are protected by Intellectual Property Rights law, including Copyright law. Copyright, IPR and Moral Rights for the works on this site are retained by the individual authors and/or other copyright owners. Terms and conditions for use of this material are defined in the policies page.

\section{CLoK}

Central Lancashire online Knowledge www.clok.uclan.ac.uk

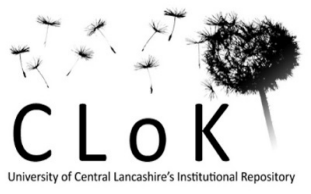




\section{Read-Across of 90-day Rat Oral Repeated-Dose Toxicity: A Case Study for Selected n-Alkanols}

4 Terry W. Schultz ${ }^{*}$, Katarzyna R. Przybylak ${ }^{2}$, Andrea-Nicole Richarz ${ }^{2}$, Claire L. Mellor ${ }^{2}$, Sylvia E. Escher ${ }^{3}$, Steven P Bradbury ${ }^{4}$ and Mark T.D. Cronin ${ }^{2}$

$7 \quad{ }^{1}$ The University of Tennessee, College of Veterinary Medicine, 2407 River Drive, Knoxville, TN 8 37996-4543 USA; ${ }^{2}$ Liverpool John Moores University, Byrom Street, L3 3AF Liverpool United 9 Kingdom; ${ }^{3}$ Fraunhofer ITEM, Nikolai-Fuchs-Str. 1, 30625 Hannover, Germany; ${ }^{4}$ Department of 10 Natural Resource Ecology and Management, Department of Entomology and Toxicology Graduate Program, Iowa State University, Ames, Iowa 50011, USA

12

13 *Corresponding author: Terry W. Schultz, email: tschultz@utk.edu 


\section{Highlights}

17 - A category of saturated alcohols was created

18 - Data compilation was undertaken for the category of n-alkanaols

19 - Repeat dose NOELs were read across for low toxicity compounds

20 - In vitro data reduce uncertainty in read-across 
22 Abstract: n-Alkanols provide an excellent example where a category-approach to read-across

23 may be used to estimate the repeated-dose endpoint for a number of untested derivatives (target

24 chemicals) using experimental data for tested derivatives (source chemicals). n-Alkanols are

25 non-reactive and exhibit the unspecific, reversible simple anaesthesia or non-polar narcosis mode

26 of toxic action in that the metabolic products of the parent alcohols do not contribute to the toxic

27 endpoint evaluated. In this case study, the chemical category is limited to the readily bioavailable

28 (C5 to C13) analogues. The toxicokinetic premise includes rapid absorption via the

29 gastrointestinal tract, distribution in the circulatory system, and first-pass metabolism in the liver

30 resulting in metabolism via oxidation to $\mathrm{CO}_{2}$ and with minor elimination of oxidative

31 intermediate as glucuronides. Two analogues have experimental 90-day oral repeated-dose

32 toxicity data which exhibit qualitative and quantitative consistency. Typical findings include

33 decreased body weight, slightly increased liver weight which, in some cases, is accompanied by

34 clinical chemical and haematological changes but generally without concurrent histopathological

35 effects at the Lowest Observed Effect Level (LOEL). Chemical similarity between the analogues

36 is readily defined by a variety of structure-related properties; data uncertainty associated with

37 toxicokinetic and toxicodynamic similarities is low. Uncertainty associated with mechanistic

38 relevance and completeness of the read-across is reduced by the concordance of in vivo and in

39 vitro results, as well as high throughput and in silico methods data. As shown in detail, the 90-

40 day oral repeated-dose toxicity No Observed Effect Level (NOEL) value of $1000 \mathrm{mg} / \mathrm{kg} \mathrm{bw} / \mathrm{d}$ for

41 1-pentanol and 1-hexanol based on LOEL of very low systemic toxicity can be read across to fill

42 the data gaps of the untested analogues in this category with acceptable uncertainty.

43 Keywords: read-across, n-alkanols, repeated-dose toxicity, No Observed Effect Level (NOEL),

44 Lowest Observed Effect Level (LOEL), weight-of-evidence (WoE), uncertainty 


\section{Introduction}

$47 \quad 1.1$ Read-across

48 The principal philosophy of a toxicological read-across is chemicals that are similar in molecular

49 structure will exhibit similar chemical properties, and as such, they will exhibit similar

50 toxicokinetic and toxicodynamic properties. Thus, experimentally-derived toxicokinetic and

51 toxicodynamic information and data from one chemical, the source substance, can be read across

52 to fill the data gap for a second chemical, the target substance which is similar. This type of data

53 gap filling is particularly useful for cosmetic ingredients where in vivo testing in Europe is

54 prohibited by legislation [1].

55 As a predictive tool, read-across has been used by industry and regulators for decades [2]. With

56 advances in non-animal test methods, read-across today is held to a different standard than at the

57 turn of the century. Specifically, there is greater expectation in terms of the identifying

58 similarities and addressing uncertainties within the read-across argument [3].

59 In order to facilitate the development of better practical guidance on how to formulate high

60 quality read-across justifications, a series of case studies have been conducted by the authors.

61 This case study illustrates specific considerations where metabolism of all the analogues in the

62 chemical category is highly similar and plays no role in determining toxicological similarity [4].

63 The case study is also intended to illustrate how non-animal data, in the form of high throughput

64 screening (HTS) data and in silico molecular screening, may be used to reduce uncertainties, as

65 well as, add to mechanistic plausibility and weights-of-evidence (WoE) to any read-across

66 argument.

67 While it is easy to establish similarity based on structure and chemical properties, this similarity

68 alone is often not enough to accept a toxicological read-across prediction for sub-chronic and 
69 chronic health endpoints. To justify the applicability domain of the category it is often necessary

70 to establish toxicodynamic, and to a greater extent toxicokinetic, similarity within the category.

71 The purpose of this research was to demonstrate the how read-across predictions of the repeated-

72 dose toxicity no observed effect level (NOEL) value based on a consistent set of lowest observed

73 effect level (LOEL) symptoms could be performed and substantiated for a category of n-alkanol

74 analogues. Specifically, the category based data providing information to reduce uncertainties,

75 and add to the WoE associated with read-across predictions of specified in vivo data. Thus, the

76 estimations from the read-across are quantitative and with sufficiently low uncertainty that they

77 may be used in risk assessments. As such, the predicted 90-day repeated-dose NOEL values are

78 accompanied by sufficient relevant in vivo and non-animal test data to make the uncertainties

79 equal to what would be expected from running a test using a protocol similar to Organization for

80 Economic Co-Operation and Development (OECD) TG 408. In the present study, a previously

81 reported 'strategy' was employed to assess similarities and overall completeness of the read-

82 across [5].

83 1.2 C5 - C13 n-alkanols: overview of existing knowledge

84 Historically, intermediate chain-length n-alkanols are considered nonpolar narcotics which act

85 mechanistically in a manner similar to depressant anaesthetics. Fang, McKim, Koleva and their

86 co-workers [6-8] reported multiple-regression type quantitative structure-toxicity relationships

87 (QSARs) for oral $\log \mathrm{LD}^{-1}$ data for rodents and the 1-octanol/water partition coefficient (log

88 Kow). Comparison of measured toxicity data with predictions from baseline QSARs reveals that

89 saturated monohydric alcohols consistently behave as classic nonpolar narcotics [9]. 
90 The efficacy of n-alkanols to induce ataxia [10] and enzyme release from liver cells [11] has

91 been interpreted as being due to the hydrophobic property of the alkanols. Perfused rat liver

92 toxicity data from Strubelt et al. [12] for 1-pentanol (exposure $65.1 \mathrm{mmol} / \mathrm{l}$ for 2 hours) are

93 reported in Table 1. These data support the premise that mammalian ex vivo toxicity (e.g., $\mathrm{O}_{2}$

94 consumption and ATP production) of $n$-alkanols is due to membrane partitioning resulting in

95 loss of membrane integrity (i.e., cytosolic enzyme leakage (LDH) but not glutathione (GSH)

96 binding).

97 Table 1. In vitro toxicity profiles for 1-pentanol.

98 LDH - lactate dehydrogenase; ATP - adenosine triphosphate; GSH - reduced glutathione

\begin{tabular}{llllll}
\hline Name & log Kow & $\begin{array}{l}\mathbf{O}_{2} \text { consumption } \\
(\mu \mathbf{m o l} / \mathbf{g} \times \mathbf{~ m i n})\end{array}$ & $\begin{array}{l}\text { ATP } \\
(\mu \mathbf{m o l} / \mathbf{g})\end{array}$ & $\begin{array}{l}\text { LDH } \\
(\mathbf{U} / \mathbf{l})\end{array}$ & $\begin{array}{l}\text { GSH } \\
(\boldsymbol{\mu m o l} / \mathbf{g})\end{array}$ \\
\hline Control & & $1.54 \pm 0.07$ & $1.25 \pm 0.20$ & $1109 \pm 265$ & $2.52 \pm 0.29$ \\
1-Pentanol & 1.40 & $0.06 \pm 0.01$ & $0.20 \pm 0.03$ & $28959 \pm 4142$ & $2.82 \pm 0.36$ \\
\hline
\end{tabular}

99

100 Due to bioavailability, and distribution and mechanistic considerations, the applicability domain

101 for this case study is limited to n-alkanols with a carbon atom (C) chain length range of C5 to

102 C13. For example, since longer-chain derivatives are typically transported via carrier molecules,

103 they are not included in this chemical category. Also, shorter-chain derivatives are not included

104 in this chemical category, as they have the potential to volatilise.

105 The general anaesthetic potency of several members of this homologous series of saturated

106 aliphatic alcohols was determined in tadpoles, using the loss of righting reflex as the criterion of

107 anaesthesia [13]. In this series, anaesthetic potency increased with chain length and was maximal

108 for 1-dodecanol. The cut-off in potency was between C12 and C14, such that 1-tridecanol was a

109 partial anaesthetic.

110 n-Alkanols within the range C5-C13 are expected to be readily absorbed by the gastrointestinal

111 tract and distributed in the blood in solution. n-Alkanols are metabolised mainly in the liver via 
112 alcohol dehydrogenase to corresponding aldehydes and, subsequently, by aldehyde

113 dehydrogenase to the corresponding carboxylic acids [14]. The fatty acid derivatives of

114 intermediate size $n$-alkanols are readily taken up by mitochondria, where they are degraded by $\beta$ -

115 oxidation, especially in hepatocytes and myocytes [14]. However, generally $<10 \%$ of the dose of

116 these primary alcohols form glucuronic acid conjugates which are excreted in the urine [15].

117 Voskoboinikova [16] and Opdyke [17] have summarised the historical literature on aliphatic

118 alcohol toxicity. More recently, the toxicity of alkanols containing from one to six C-atoms has

119 been reviewed [18]. A cursory summary of the rat oral acute and oral repeated-dose toxicity of

120 intermediate size n-alkanol are presented in Table 2. In general, n-alkanols acute oral toxicity

121 (i.e., LC50) is very low, ranging from 1500 to $5000 \mathrm{mg} / \mathrm{kg}$ bw with an average value of $\approx 3000$

$122 \mathrm{mg} / \mathrm{kg}$ bw. n-Alkanols are only slightly toxic in oral repeated-dose testing; typically, the rodent,

123 oral, 90-day, repeated-dose NOEL in $\mathrm{mg} / \mathrm{kg}$ bw/d is in the range of 1/2 - 1/3 the LC50 value.

124 This value is characteristically based on clinical symptoms, haematological values outside the

125 normal range, or whole body effects different from normal. However, if ingested in large enough

126 quantities (i.e., near lethal doses), n-alkanols have the potential to cause systemic damage to the

127 liver, heart, kidneys, and/or nervous system (see citations in Table 2 for details).

128 Table 2. Rat oral acute and repeated-dose toxicity of selected n-alkanols.

\begin{tabular}{lllll}
\hline Alcohol & $\begin{array}{l}\text { Oral LD50 } \\
(\mathbf{m g} / \mathbf{k g})\end{array}$ & Reference & $\begin{array}{l}\text { 90-d Oral NOAEL } \\
(\mathbf{m g} / \mathbf{k g} \text { bw/d) }\end{array}$ & Reference \\
\hline 1-Pentanol & 2200 & {$[19]$} & 1000 & {$[20]$} \\
& 3645 & {$[21]$} & 1000 & {$[21]$} \\
1-Hexanol & 4590 & {$[22]$} & $1127 \mathrm{M}$ & {$[23]$} \\
& 4870 & {$[24]$} & $1243 \mathrm{~F}$ & {$[23]$} \\
1-Heptanol & 3250 & {$[24]$} & $>1000$ & {$[26]$} \\
& $6200 \mathrm{M}$ & {$[25,26]$} & & \\
\hline
\end{tabular}




\begin{tabular}{lccll}
\hline 1-Octanol & $>5000$ & {$[27]$} & Not determined & \\
$\begin{array}{l}\text { Nonyl alcohol (assumed } \\
\text { 1-nonanol) }\end{array}$ & 3560 & {$[17]$} & Not determined & \\
$\begin{array}{l}\text { 1-Decanol } \\
\text { Undecyl alcohol }\end{array}$ & 4720 & {$[28]$} & Not determined & \\
$\begin{array}{l}\text { (assumed 1-undecanol) } \\
\text { Lauryl alcohol (assumed }\end{array}$ & $>2000$ & {$[29]$} & $2000^{\mathrm{a}}$ & {$[30]$} \\
$\begin{array}{l}\text { 1-dodecanol) } \\
\text { 1-Tridecanol }\end{array}$ & {$[31]$} & 2000 & {$[31,32]$} \\
\end{tabular}

${ }^{a}$ NOAEL value is recorded as experimental result, but the details in the report indicate that it is read across from 1-dodecanol 130 (CAS 112-53-8).

$131 \quad$ M- male, F- female

\section{2. Method and Materials}

134 This evaluation of selected n-alkanols follows the workflow of Przybylak et al. [5]. It is in accord 135 with the guidelines proposed by OECD [34] and Schultz and co-workers [35]. In vivo data used 136 in the assessment were taken from the literature, including ECHA REACH Registered

137 Substances database [36]. Mechanistic relevance, as well as toxicokinetic and toxicodynamic

138 similarity of the category analogues was established using relevant non-animal data.

$139 \quad 2.1$ Target and Source Substances

140 In this case study, the analogues (listed in Table 3) include seven target and two source

141 chemicals; the latter, those with repeated-dose data derived from a 90-day OECD TG 408 assay,

142 are noted in bold print. This list is inclusive, as defined by the limitations of the applicability

143 domain. The analogues represents n-alkanols which are found in governmental or industrial

144 inventories (e.g., OECD High Production Volume Chemicals). Additional substance identifier

145 information, such as chemical structures and molecular formulas, are available in Table 1 of the

146 supplemental information.

147 Table 3. n-Alkanols considered as part of the chemical category for read-across. Compounds in 148 bold indicate the source substances. 


\begin{tabular}{llll}
\hline ID & Name & CAS No. & SMILES \\
\hline 1 & 1-Pentanol & $\mathbf{7 1 - 4 1 - 0}$ & CCCCCO \\
2 & 1-Hexanol & $\mathbf{1 1 1 - 2 7 - 3}$ & CCCCCCO \\
3 & 1-Heptanol & $111-70-6$ & CCCCCCCO \\
4 & $1-$ Octanol & $111-87-5$ & CCCCCCCCO \\
5 & $1-$ Nonanol & $143-08-8$ & CCCCCCCCCO \\
6 & $1-D e c a n o l$ & $112-30-1$ & CCCCCCCCCCO \\
, & $1-$ Undecanol & $112-42-5$ & CCCCCCCCCCCO \\
8 & 1-Dodecanol & $112-53-8$ & CCCCCCCCCCCCO \\
9 & 1-Tridecanol & $112-70-9$ & CCCCCCCCCCCCCO \\
\hline
\end{tabular}

151 The NOEL for the 90-day rat oral repeated-dose is the single endpoint for which this category

152 approach is applied. The 90-day oral repeated-dose data for 1-pentanol and 1-hexanol are

153 particularly well-suited for read-across; the NOELs are based on experimental results from a 4-

154 dose exposure scenario $(0,<100$, between 100 and 500 , and $\geq 1000 \mathrm{mg} / \mathrm{kg} \mathrm{bw} / \mathrm{d})$ following a

155 standard test guideline (OECD TG 408) where the LOEL symptoms are reported. Moreover,

156 there are supporting repeated-dose results for 1-heptanol, 1-undecanol and 1-dodecanol from

157 OECD TG 422 studies, with the exposure durations for males being 28 days and for females 54

158 days.

1592.3 Hypothesis of the category

160 The premise for this read-across case study is:

161 - n-Alkanols of intermediate chain length (i.e., C5 to C13) are direct acting toxicants (i.e.,

162 metabolic activation and detoxification is not a factor in toxicity) with a similar reversible

163 mode of action (i.e., non-polar narcosis or simple anaesthesia). 
- Within $\mathrm{C} 5$ to $\mathrm{C} 13$ derivatives, $\mathrm{C}$-atom chain length affects most physico-chemical properties (e.g., Log Kow values increase with increasing chain length). However, this trend, while toxicologically relevant in fish toxicity and in vitro assays, is not observed in mammalian acute and sub-chronic toxicity via oral exposure.

\subsection{Read-across justification}

In order to conduct a read-across, there is the requirement for high quality in vivo data for the

181 endpoint under consideration [5, 34, 35]. In this case, is 90-day oral repeated dose-toxicity for

182 rats in the form of a NOEL value and LOEL symptoms from a study similar to OECD TG 408.

183 From a repeated-dose perspective, test results of $n$-alkanols are extensive. 1-Pentanol was orally 184 administered to rats following OECD TG 408 at dose levels of $0,50,150$ or $1000 \mathrm{mg} / \mathrm{kg} \mathrm{bw} / \mathrm{d}$ 
185 for 13 weeks [20, 21]. The "no-outward-effect level" (assumed to be the NOEL) was 1000

$186 \mathrm{mg} / \mathrm{kg} / \mathrm{day}$.

187 In a non-standard rat oral repeated-dose assay similar to an OECD TG 408 assay, animals were 188 exposed to $0.25 \%$ (based on nominal concentrations in the diet) and $0.50 \%$ for 13 weeks; $1.0 \%$ 189 for 10 weeks, then $2.0 \%$ (week 11), $4.0 \%$ (week 12) and 6.0\% 13 weeks of 1-hexanol [23]. The

190 NOAEL for 1-hexanol was determined to be $\approx 1100 \mathrm{mg} / \mathrm{kg} \mathrm{bw} / \mathrm{d}(1127 \mathrm{mg} / \mathrm{kg} \mathrm{bw} / \mathrm{d}$ for male and $1911243 \mathrm{mg} / \mathrm{kg} \mathrm{bw} / \mathrm{d}$ for female rats).

192 While the endpoint read across in this exercise is the 90-day oral repeated-dose NOEL, there is 193 also high quality repeated-dose toxicity NOEL/LOEL data for shorter duration studies (e.g., 194 OECD TG 422). Since these data are both qualitatively and quantitatively similar to the 90-day 195 data, they may be used as WoE and to confirm that all category members are within the endpoint 196 domain.

197 1-Heptanol was administered orally to rats under OECD TG 422 and 0, 100, 300 and 1000 $198 \mathrm{mg} / \mathrm{kg} \mathrm{bw} / \mathrm{d}$ [26]. No treatment related changes were noted for all parameters (e.g., biochemical, 199 haematological and clinical parameters, as well as body weight, food consumption and 200 neurobehavioral effects).

201 Following OECD TG 422, oral repeated-dose toxicity of 1-undecanol in rats was evaluated at 202 doses of $\approx 0,100,500,2000 \mathrm{mg} / \mathrm{kg} \mathrm{bw} / \mathrm{d}[30]$. A NOEL for systemic toxicity of $2000 \mathrm{mg} / \mathrm{kg}$ $203 \mathrm{bw} / \mathrm{d}$ was determined in male rats, in the absence of toxicologically significant effects at any 204 dose level. 
205 Following OECD TG 422, rats were exposed to 1-dodecanol in the diet in concentrations of $\approx 0$,

206100,500 and $2000 \mathrm{mg} / \mathrm{kg} / \mathrm{bw} / \mathrm{d}$ [31]. A NOEL for systemic toxicity of $2000 \mathrm{mg} / \mathrm{kg}$ bw/d was

207 determined in male rats, in the absence of toxicologically significant effects at any dose level.

208 In summary, while protocols vary, results for repeated-dose toxicity test results exhibit

209 qualitative and quantitative consistency. Phenotypic results from repeated exposure to n-alkanols

210 reflect mild changes consistent with low-grade effects and include decreased body weight,

211 accompanied by clinical chemical and haematological changes, but generally without concurrent

212 histopathological effects.

213 3.2 Applicability domain

214 As previously noted, the applicability domain for this case study is confined to straight-chain

215 primary alkanols of intermediate size, $\mathrm{C} 5$ to $\mathrm{C} 13$.

216 3.3 Purity/impurities

217 Read-across is based on the structural similarity of the main constituents of the source and target

218 substances. Toxicity may actually be determined by an impurity, therefore it is important to

219 provide a purity/impurity profile for all analogues. However, in this case it was not possible to

220 take into account impurities based on production. Since the category is structurally limited, the

221 impurities are expected to be similar if not the same across the members and are not expected to

222 significantly impact the toxicity profile of any analogue. However, it is acknowledged for

223 regulatory decisions such information may be required.

2243.4 Data matrices for assessing similarity 
225 In order for a read-across prediction to be accepted, there is the requirement to establish

226 similarity between the source and target substance $[5,34,35]$. While structural similarity is a

227 minimum, toxicokinetic similarity, especially for metabolism, and toxicodynamic similarity,

228 especially in regard to mechanistic plausibility, is required for sub-chronic endpoints such as 90-

229 day oral repeated dose-toxicity [5].

$230 \quad 3.4 .1$ Structural similarity

231 As demonstrated in Tables 1 and 3 of the supplemental information, all the n-alkanols included

232 in the category are structurally highly similar. Specifically, they: 1) belong to a common

233 chemical class, aliphatic alcohols and subclass, n-alkanols, and 2) possess common molecular

234 scaffolding, a C-atom backbone with a straight-chain configuration. Structurally, the only

235 variable is the length of the hydrocarbon backbone, C5-C13.

$236 \quad 3.4 .2$ Chemical property similarity

237 As demonstrated in Table 2 of the supplemental information, all the n-alkanols included in the 238 category have many of their physico-chemical properties determined experimentally. Thus, when

239 required calculated values, which are based on these measured values can be accepted with high

240 confidence. Properties, with the exception of density and $\mathrm{pKa}$, trend in value related to $\mathrm{C}$-atom

241 number within the scaffold. Specifically, all category members exhibit molecular weights from

24288 to $200 \mathrm{~g} / \mathrm{mol}$. Hydrophobicity (as modelled by $\log \mathrm{Kow}$ ) increases with number of C-atoms

243 from $>1.0$ to $<6.0$, vapour pressure and water solubility decrease with molecular size, melting

244 point and boiling point increase with molecular size, and density is constant at $0.8 \pm 0.1 \mathrm{~g} / \mathrm{cm}^{3}$.

245 Since there is no readily ionisable substituent the $\mathrm{pKa}$ is consistent at $\approx 15.2$.

$246 \quad 3.4 .3$ Chemical constituent similarity 
247 As shown in Table 3 of the supplemental information, all the n-alkanols included in the category

248 have common constituents in the form of: 1) a single key substituent, - $\mathrm{OH}$, and 2) structural

249 fragments, $-\mathrm{CH}_{3}$ and $-\mathrm{CH}_{2}-$

$250 \quad 3.4 .4$ Toxicokinetic similarity

251 Limiting the range of $\mathrm{C}$-atoms for the applicability domain reduced the impact of size on

252 adsorption, distribution, metabolism and elimination (ADME). From a bioavailability standpoint,

253 the analogues exhibit in in silico models linear trend with molecular weight. Such modelling

254 reflects hydrophobic-dependent uptake.

255 The toxicokinetic understanding of alkanols is reasonably complete despite the fact that the 256 experimental data, as summarised in Table 4 of the supplemental information, are limited.

257 Absorption, distribution and elimination are not considered factors in these predictions. For

258 example, 1-octanol is rapidly absorbed after oral administration (i.e., bioavailability $>80 \%$ ). 1 -

259 Octanol is excreted mainly as $\mathrm{CO}_{2}$, and to a lesser extent as n-octyl glucuronide [17, 27, 37].

260 Other n-alkanols exhibit similar toxicokinetics, with n-alcohols generally forming $<10 \%$ of the

261 dose as glucuronic acid conjugates and are excreted in the urine [15].

262 It is generally accepted that, regardless of species, metabolism of n-alkanols is highly efficient

263 and proceeds in a similar fashion [38]. Basically, there only degradative or detoxification

264 pathways involved in the metabolism of n-alkanols. It is universality accepted that in the first

265 step of the biotransformation, the alcohols undergo stepwise intracellular oxidation to the

266 corresponding carboxylic acids, followed by a stepwise $\mathrm{C} 2$ unit elimination via mitochondrial $\beta$ -

267 oxidation [38]. 
269 As demonstrated in Table 5 of the supplemental information, all of the category members

270 undergo oxidation and hydroxylation in metabolic simulations. Briefly, mammalian catabolism

271 of fatty acids, which most often takes place in the mitochondria, leads to the formation of acetyl-

272 coenzyme A (CoA), enters the TCA cycle and reduces nicotinamide adenine dinucleotide

$273(\mathrm{NADH})$ and flavin adenine nucleotide (FADH2) which are used by the electron transport chain

274 to produce ATP [14].

275 While other processes, including $\omega$-oxidation and $\alpha$-oxidation, are known to take place, $\beta$ -

276 oxidation is the most common catabolic process in n-alkanol metabolism. It is highly likely that

277 the n-alkanols included in the category will be nearly completely metabolised (i.e., >90\%) via

278 the tricarboxcylic acid (TCA) cycle. It is generally agreed that cytosolic fatty acids are activated

279 for degradation by conjugation with CoA. $\beta$-Oxidation of saturated fatty acids consists of a

280 recurring cycle of four reactions [14]. In acids with an even number of C-atoms, this cycling

281 continues until two molecules of Acetyl-CoA are produced in the final reaction. Acetyl-CoA is

282 available to be further metabolised in the TCA cycle. In acids with an odd number of C-atoms,

283 the end product is propionyl-CoA, which must be converted to succinyl-CoA to enter the TCA 284 cycle.

285 3.4.6 Toxicophore similarity

286 The severe limitation of the structural domains sharply reduces the likelihood of differences in

287 toxicophores between the target and source analogues. As demonstrated in Table 6 of the

288 supplemental information, none of the n-alkanols included in the category are associated with

289 any toxicophore based on in silico profilers within the OECD QSAR Toolbox V3.4. 
291 While there is no mammalian adverse outcome pathway for the hypothesized mode of action, it

292 is generally accepted that the acute toxicity of intermediate chain n-alcohols is the result of

293 narcosis [5-9]. There are both theoretical and biochemical evidence for the cell membrane being

294 the site of action for anaesthetic-like chemicals [10-11]. Narcosis, in the broadest sense, is the

295 reversible, non-covalent disruption of hydrophobic interactions within membranes with a

296 particular volume fraction, rather than molar fraction [39]. It is the accumulation of alcohols in

297 cell membranes which disturbs their function; however, the exact mechanism is not yet known.

298 There are three competing theories of general anaesthetic action: 1) the lipid solubility-

299 anaesthetic potency correlation (i.e., the Meyer-Overton correlation), 2) the modern lipid

300 hypothesis, and 3) the membrane protein hypothesis [c.f., 40-41].

301 As stated in Table 7 of the supplemental information, the n-alkanols included in the category are

302 associated with the simple narcosis mechanism of toxicity that is equivalent to depressant

303 anaesthetics [6]. Additivity of primary alkanols in joint effect studies was demonstrated in

304 injection anaesthesia studies in rats [6],. This observation of additivity is consistent with the

305 premise that n-alkanols exhibit a common mechanism of action. More importantly, Fang et al.

306 [6] demonstrated additivity or slight deviations from additivity for alkanols with the conventional

307 inhaled anaesthetic desflurane (1,2,2,2-tetrafluoroethyl difluoromethyl ether). The latter support

308 the contention that the mechanisms of action of n-alkanols is depressant anaesthesia.

309 The effect of various primary alkanols on the CNS was studied by using rat brain synaptosomal

310 membranes as an in vitro model [41]. The activity of $\left(\mathrm{Ca}_{2}{ }^{+} / \mathrm{Mg}_{2}{ }^{+}\right)$ATPase and the membrane

311 fluidity were determined. Specifically, the n-alkanols exhibited an increased molar inhibition of

312 the ATPase activity, with an increase in the carbon chain length up to 1-octanol. 1-Octanol and

313 1-decanol caused a biphasic effect on the ATPase activity, depending on the n-alkanol 
314 concentration, whereas 1-dodecanol caused a stimulation of the ATPase activity. All alkanols

315 studied caused an increased fluidity of the membrane; however, changes in the membrane

316 fluidity do not seem to be a pre-requisite of the ATPase inhibition [41].

317 The Fish Acute Toxicity Syndrome (FATS) approach put forth by McKim et al. [7] has furthered

318 our mechanistic understanding and the effects of intermediate chain saturated alcohols in fish

319 more than anything else. The FATS approach is based on physiological response sets from

320 spinally transected rainbow trout (Oncorhynchus mykiss) exposed to model chemicals. Briefly, in

321 vivo biochemical and respiratory-cardiovascular responses were measured during lethal aqueous

322 exposures; the responses and their interdependence formed a complex data matrix, with the best

323 response variables for mechanisms of action being determined with multivariate statistics. The

324 FATS for 1-octanol is characterised by a striking slow-down in all respiratory and cardiovascular

325 functions [7] that makes it distinct from other modes of actions. The action of 1-octanol is

326 consistent with depressant anaesthesia.

327 The contributions of functional groups in acute rat oral toxicity have been calculated using

328 alkanes as the baseline [40]. The toxic contribution of the $\mathrm{OH}$ group is -0.108 . This situation

329 (negative contribution to toxicity as compared to corresponding alkane) has not been observed in

330 acute fish toxicity because the threshold of excess toxicity is too high to distinguish differences

331 in toxicity. Critical body residues (CBRs) calculated from percentage of absorption and

332 bioconcentration factors indicate that most of aliphatic alcohols share the same modes of toxic

333 action between fish and rat. Specifically, fish and rat $\log (1 / \mathrm{CBR})$ and number of alcohols are

$3341.65 ; 18$ and $1.58 ; 348$, respectively [40]. 
335 In summary, there are several lines of evidence that support the contention that all the analogues

336 within the domain act in a similar fashion and that fashion is not different from simple

337 anaesthesia or non-polar narcosis.

$338 \quad 3.4 .8$ Other in vivo endpoint similarity

339 In mammals, alkanols are considered baseline inhalation toxicants which model as simple

340 narcotics [9]. Based on acute oral toxicity, n-alkanols belong to Category 4 which do not require

341 a hazard label for acute oral toxicity. Their LD50 values are very low, typically ranging from

3421000 to $>5000 \mathrm{mg} / \mathrm{kg}$ bw with an average value of $\approx 3000 \mathrm{mg} / \mathrm{kg}$ bw (see Table 2 ). In mammals,

343 mild to moderate sub-lethal toxicity from a single oral dose of intermediate size alkanols include

344 general gastrointestinal symptoms (e.g., nausea, vomiting, abdominal cramps and diarrhoea)

345 associated with irritation. High ingested doses (i.e., near acute lethal levels) can cause

346 gastrointestinal haemorrhage and liver injury. For example, in the rat, the LD50 for 1-octanol is

$347>5000 \mathrm{mg} / \mathrm{kg}$ [17]; the only symptoms of intoxication observed were moderately to severely

348 ruffled fur and mild sedation. The symptoms had disappeared completely 24 hours later. The

349 growth of the exposed animals was similar to that of the controls.

350 In fish, alkanols are considered to act via the nonpolar narcosis mode of action $[42,43]$. Within

351 the USEPA DSSTox Fathead Minnow Acute Toxicity (EPAFHM) database, alkanols are

352 represented. They exhibit toxic potencies not statistically different from baseline predictions.

353 Because of concerns for aquatic toxicity, a large number of alcohols, especially saturated ones,

354 have been tested in vitro for cell population growth inhibition [44]. Structure-activity results

355 from in vivo and in vitro tests are highly consistent [45]. Briefly, from a structural standpoint, the

356 aquatic toxicity of alkanols is partition-dependent, regardless of endpoint being assessed. 
357 Generally, for alkanol exposures in in vitro assays, results are attributed to unspecific

358 interactions with biological membranes [11]; such effects are typically directly correlated with 1-

359 octanol/water partition coefficients (c.f. [46]).

$360 \quad 3.4 .9$ Relevant in vitro and in silico data

361 In an effort to further support the mechanistic argument for this read-across information form

362 two new methods were examined. Specifically, relevant HTS data in the form of ToxCast data

$363[47,48]$ and of in silico nuclear receptor binding predictions [49] were evaluated. Within the

364 USEPA toxicity forecaster program (ToxCast) [50], data are available for the majority of the n-

365 alkanol derivatives (see Table 8 of the supplemental information). Of the 711 possible assays

366 that form the ToxCast scheme, 1-octanol, 1-undecanol, 1-dodecanol and 1-tridecanol have been

367 evaluated in 602 of them. Additionally, 1-hexanol, 1-heptanol and 1-decanol have been assessed

368 in about 250 assays. Lastly, 1-nonanol has been tested in 150 ToxCast assays. The number of

369 active assays varies from none for 1-octanol to 25 for 1-undecanol and 30 for 1-tridecanol.

370 Within ToxCast, the n-alkanols are among the "least promiscuous chemical classes"; $<2.74 \%$ of

371 the ToxCast assays showing any activity up to highest concentration tested and none of the

372 active assay are associated with specific bioactivity.

373 Only four non-specific cell viability qHTS assays within the Toxcast suite were positive for four

374 of the tested n-alkanol analogues; no assay exhibits activity for five or more of the category

375 analogues. Specifically, the Tox21_ELG1_LUC_Agonist_viability,

376 Tox21_TR_LUC_GH3_Antagonist_viability, Tox21_AhR_viability and

377 Tox21_Aromatase_Inhibition_viability show a positive response with four n-alkanols but there is 378 no consistency among which analogues are positive. 
Alkanols were screened with a variety of in silico profilers [49]. Specifically, profilers for

380 nuclear receptor binding were run to identify potential binding to the following nuclear

381 receptors; PPARs (peroxisome proliferator-activated receptors), AR (androgen receptor), AHR

382 (aryl hydrocarbon receptor), ER (oestrogen receptor), GR (glucocorticoid receptor), PR

383 (progesterone receptor), FXR (farnesoid X receptor), LXR (liver X receptor), PXR (pregnane X

384 receptor), THR (thyroid hormone receptor), VDR (vitamin D receptor), as well as RAR/RXR

385 (retinoic acid receptor/ retinoid X receptor). The evaluation of potential binding to the receptors

386 is based on structural fragments and physico-chemical features that have been identified as

387 essential to bind to these nuclear receptors and induce a response. As noted in Table 6 of the

388 supplemental information, no potential receptor binding was predicted. It is worth noting that

389 ToxCast also tested for all of these receptors, and all corresponding assays were negative.

390 Taken collectively, the HTS and in silico findings are not inconsistent with the cited in vivo data.

391 The premise that, oral repeated-dose toxicity of n-alkanols are considered to be nonpolar

392 narcotics and act in a manner similar to depressant anesthetics is consistent with the ToxCast

393 data and receptor binding simulations results which indicate no activity associated with a specific

394 mode of action.

\section{4. Statement of uncertainty}

397 The categorical assessments of uncertainties along with summary comments are presented in

398 Tables 4 and 5. Briefly, chemical similarity is limited by chain length but has no impact on

399 repeated-dose toxicity. Data uncertainty with the fundamental aspects of toxicokinetics is low.

400 Regardless of the species of mammals, all such category members are judged to be readily

401 absorbed orally and to have similar distributions; metabolised via oxidation to the acid 
402 derivative, subsequently degraded to $\mathrm{CO}_{2}$ via mitochondrial oxidation, and/or eliminated as a

403 glucuronide. Data uncertainty with the fundamental aspects of toxicodynamics is low, in that

404 category members exhibit a very low-toxic profile with respect to in vivo effects (i.e., NOEL and

405 LOEL), as well as with respect to in vitro and new-methods effects. n-Alkanols are

406 experimentally associated with the nonpolar narcosis mechanisms of toxicity. The simple

407 narcosis (i.e., reversible anaesthesia) mode of toxic action is driven by partitioning into the

408 biophase. While well-studied, this molecular mechanism is not well-understood and no adverse

409 outcome pathway (AOP) is currently available. Moreover, it is unclear if oral repeated-dose

410 toxicity is related to this mechanism; however, there is no evidence to suggest it is not.

411 Uncertainty associated with mechanistic relevance and completeness of the read-across (i.e.,

412 uncertainty in the predictions) while initially low-to-moderate is reduced to low with the addition

413 of ToxCast and in silico screening data. The major source of uncertainty for this group of

414 alcohols is associated with what is essentially a "low-toxic" prediction.

415 Table 4. Assessment of data uncertainty and strength-of-evidence associated with the 416 fundamentals of chemical, transformation/toxicokinetic and toxicodynamic similarity.

\begin{tabular}{|c|c|c|c|}
\hline $\begin{array}{l}\text { Similarity } \\
\text { Parameter }\end{array}$ & $\begin{array}{c}\text { Data } \\
\text { Uncertainty }^{\mathrm{a}}\end{array}$ & $\begin{array}{l}\text { Strength-of- } \\
\text { Evidence }^{\text {b }}\end{array}$ & Comment \\
\hline $\begin{array}{l}\text { Substance } \\
\text { identification, } \\
\text { structure and } \\
\text { chemical } \\
\text { classifications } \\
\end{array}$ & low & high & $\begin{array}{l}\text { All category members are discrete organic substance } \\
\text { of simple structure. They all have CAS numbers, } \\
\text { similar 2D structure and belong to the same chemical } \\
\text { class (primary aliphatic alcohols) and same subclass } \\
\text { (straight-chain alcohols). }\end{array}$ \\
\hline \multirow[t]{2}{*}{$\begin{array}{l}\text { Physio-chem \& } \\
\text { molecular } \\
\text { properties }\end{array}$} & $\begin{array}{l}\text { Empirical: } \\
\text { low }\end{array}$ & high & $\begin{array}{l}\text { All category members are appropriately similar with } \\
\text { respect to key physico-chemical and molecular } \\
\text { properties. Where appropriate (e.g., log Kow) }\end{array}$ \\
\hline & $\begin{array}{l}\text { Modelled: } \\
\text { low }\end{array}$ & & $\begin{array}{l}\text { changes in values are linked to changes in C-atom } \\
\text { chain length. There is a high degree of consistency } \\
\text { between measured and model estimated values. }\end{array}$ \\
\hline $\begin{array}{l}\text { Substituents, } \\
\text { functional groups, } \\
\& \text { extended } \\
\text { structural } \\
\text { fragments }\end{array}$ & low & high & $\begin{array}{l}\text { Substituents and functional groups are consistent } \\
\text { across all category members. There are no extended } \\
\text { structural fragments. }\end{array}$ \\
\hline $\begin{array}{l}\text { Transformation/tox } \\
\text { icokinetics and }\end{array}$ & $\begin{array}{l}\text { Empirical: } \\
\text { in vivo: low }\end{array}$ & medium & $\begin{array}{l}\text { While in vivo absorption data are reported for only } \\
\text { one category member, there is evidence for similar }\end{array}$ \\
\hline
\end{tabular}




\begin{tabular}{|c|c|c|c|}
\hline $\begin{array}{l}\text { Similarity } \\
\text { Parameter }\end{array}$ & $\begin{array}{c}\text { Data } \\
\text { Uncertainty }^{\mathrm{a}}\end{array}$ & $\begin{array}{l}\text { Strength-of- } \\
\text { Evidence }\end{array}$ & Comment \\
\hline $\begin{array}{l}\text { metabolic } \\
\text { similarity }\end{array}$ & $\begin{array}{l}\text { Simulated: } \\
\text { low }\end{array}$ & & $\begin{array}{l}\text { toxicokinetics and metabolic pathways. Comparison } \\
\text { of results from empirical studies and model } \\
\text { predictions indicate similar metabolism among } \\
\text { category members. It is universally accepted that n- } \\
\text { alkanols are typically degraded to } \mathrm{CO}_{2} \text {. Absorption } \\
\text { and distribution are not considered factors in these } \\
\text { predictions. }\end{array}$ \\
\hline $\begin{array}{l}\text { Potential metabolic } \\
\text { products }\end{array}$ & $\begin{array}{l}\text { Simulated: } \\
\text { low }\end{array}$ & high & $\begin{array}{l}\text { Based on in silico metabolic simulations, metabolites } \\
\text { from oxidation and hydroxylation are predicted to be } \\
\text { produced by all the category members. }\end{array}$ \\
\hline $\begin{array}{l}\text { Toxicophores } \\
\text { /mechanistic alerts }\end{array}$ & medium & high & $\begin{array}{l}\text { Based on in silico profilers, no category member } \\
\text { contains any established toxicophores. }\end{array}$ \\
\hline $\begin{array}{l}\text { Mechanistic } \\
\text { plausibility and } \\
\text { AOP-related events }\end{array}$ & medium & high & $\begin{array}{l}\text { Although no AOP is currently available for the } \\
\text { hypothesized mode of action, many category } \\
\text { members have been tested for what is generally } \\
\text { accepted as mechanistically-relevant events (i.e., } \\
\text { anaesthesia and narcosis). }\end{array}$ \\
\hline $\begin{array}{l}\text { Other relevant, in } \\
\text { vivo, in vitro and ex } \\
\text { vivo endpoints }\end{array}$ & low & high & $\begin{array}{l}\text { Although not directly related to the repeated-dose } \\
\text { endpoint, many category members have been tested } \\
\text { for in vivo acute effects in rodents and fish. In } \\
\text { addition, many category members have been tested in } \\
\text { vitro for cellular effects. There is general agreement } \\
\text { in the trend of the reported EC50 values. The primary } \\
\text { alkanols are among the "least promiscuous chemical } \\
\text { classes" within ToxCast with no positive assay being } \\
\text { associated with specific bioactivity. Primary alkanols } \\
\text { reveal no propensity for nuclear receptor binding } \\
\text { within the COSMOS suite of in silico profilers. }\end{array}$ \\
\hline
\end{tabular}

${ }^{\mathrm{b}}$ Consistency within the information/data used to support the similarity rational and prediction (low, medium, high)

Table 5. Assessment of uncertainty associated with mechanistic relevance and completeness of 424 the read-across.

\begin{tabular}{|c|c|c|}
\hline Factor & $\begin{array}{l}\text { Mechanistic } \\
\text { Uncertainty }^{\text {a }}\end{array}$ & Comment \\
\hline $\begin{array}{l}\text { The problem and } \\
\text { premise of the } \\
\text { read-across }\end{array}$ & Low & $\begin{array}{l}\text { The endpoint to be read across, oral 90-day repeated-dose } \\
\text { toxicity, for n-alkanols is well-studied and fairly well-understood } \\
\text { mechanistically. The scenario of the read-across hinges on } \\
\text { metabolism not affecting toxicity and the mode of toxic action } \\
\text { being reversible narcosis. Thus, n-alkanols have no obvious } \\
\text { chemical reactivity, do not bind to any known receptor and } \\
\text { exhibit no specific mode of toxic action. }\end{array}$ \\
\hline
\end{tabular}

\section{In vivo data read-across}

\begin{tabular}{lll}
\hline $\begin{array}{l}\text { Number of } \\
\text { analogues in the } \\
\text { source set }\end{array}$ & $\begin{array}{l}\text { Low; 5of 9 } \\
\text { analogues }\end{array}$ & $\begin{array}{l}\text { While there are five tested category members, two 1-pentanol and } \\
\text { 1-hexanol, have high quality in vivo 90-day, oral repeated-dose } \\
\text { data usable for read-across. }\end{array}$ \\
\hline $\begin{array}{l}\text { Quality of the in } \\
\text { vivo apical }\end{array}$ & $\begin{array}{l}\text { Low; consistent } \\
\text { lowest observed }\end{array}$ & $\begin{array}{l}\text { Generally, the in vivo data are consistent with regard to } \\
\text { qualitative description of repeated-dose effects. LOEL affects are } \\
\text { typically haematological or whole body parameters and not }\end{array}$ \\
\hline
\end{tabular}




\begin{tabular}{|c|c|c|}
\hline $\begin{array}{l}\text { endpoint data read } \\
\text { across }\end{array}$ & $\begin{array}{l}\text { effect concentration } \\
\text { (LOEC) symptoms }\end{array}$ & $\begin{array}{l}\text { organ-specific effects. The high quality empirical data (e.g., } \\
\text { OECD TG 408) for the 90-day repeated-dose endpoint exists for } \\
\text { 1-pentanol and 1-hexanol are supported by lower quality (i.e., } \\
\text { OECD TG 422) oral repeated-dose toxicity data for 1-heptanol, 1- } \\
\text { unidecanol and 1-dodecanol. }\end{array}$ \\
\hline $\begin{array}{l}\text { Severity of the } \\
\text { apical in vivo } \\
\text { hazard }\end{array}$ & $\begin{array}{l}\text { Low; strong } \\
\text { evidence that the } \\
90 \text {-day NOAEL } \\
\text { value is } 1 / 20 \text { to } \\
1 / 10 \text { of the LD50 } \\
\text { values. }\end{array}$ & $\begin{array}{l}\text { The consensus is that n-alkanols have no obvious chemical } \\
\text { reactivity, do not bind to any known receptor and exhibit no } \\
\text { specific mode of toxic action. Potency data for the in vivo } 90-\mathrm{d} \\
\text { oral repeated-dose NOAEL are } \approx 1000 \mathrm{mg} / \mathrm{kg} \text { bw/d based on } \\
\text { general whole body effects for both sexes. }\end{array}$ \\
\hline \multicolumn{3}{|c|}{ Evidence to the biological argument for read-across } \\
\hline $\begin{array}{l}\text { Robustness of } \\
\text { analogue data set }\end{array}$ & $\begin{array}{l}\text { Low; numerous } \\
\text { endpoints reveal the } \\
\text { same structure- } \\
\text { activity } \\
\text { relationships. }\end{array}$ & $\begin{array}{l}\text { The available data from acute in vivo and in vitro studies for the } \\
\text { category members are extensive with several assays being used to } \\
\text { assess most if not all the analogues, especially the source } \\
\text { analogues. The tests were judged to be reliable and conducted } \\
\text { under the appropriate conditions. }\end{array}$ \\
\hline $\begin{array}{l}\text { Concordance with } \\
\text { regard to the } \\
\text { intermediate and } \\
\text { apical effects and } \\
\text { potency data }\end{array}$ & $\begin{array}{l}\text { Low to medium; } \\
\text { limited by indirect } \\
\text { rationale (e.g., acute } \\
\text { to chronic) of } \\
\text { mechanistic } \\
\text { plausibility. }\end{array}$ & $\begin{array}{l}\text { Since there is no toxicity pathway for repeated-dose effects for } \\
\text { this chemical category, there are no true intermediate events. } \\
\text { However, there is concordance between anaesthesia and slow- } \\
\text { down in all respiratory and cardiovascular functions. There is } \\
\text { agreement among the dose-response relationships of the tested } \\
\text { category members for other relevant endpoints. }\end{array}$ \\
\hline $\begin{array}{l}\text { Weight-of- } \\
\text { Evidence }\end{array}$ & $\begin{array}{l}\text { High; experimental } \\
\text { and predicted } \\
\text { information among } \\
\text { and between the } \\
\text { category member is } \\
\text { consistent with } \\
\text { stated premise }\end{array}$ & $\begin{array}{l}\text { Overall the available information is generally consistent with the } \\
\text { stated premise. The structural limitations (i.e., n-alkanols) on the } \\
\text { category strengthen the weight-of -evidence (WoE). While the } \\
\text { toxicokinetics data are limited, the consistency in metabolism and } \\
\text { simplicity of the metabolic pathway adds to the WoE. The fact the } \\
\text { source substances in vivo data is supported by similar data for } \\
\text { other analogues adds to the WoE. The fact that there is consistent } \\
\text { relevant in vitro data for most category members strengthens the } \\
\text { WoE. The consistency in results as related to simple membrane } \\
\text { partitioning strengthens the WoE. The consistent negative results } \\
\text { with ToxCast assays and screening with in silico receptor-binding } \\
\text { profilers add to the WoE. }\end{array}$ \\
\hline
\end{tabular}

425 ancertainty: low, medium, high

426 5. Statement of the conclusions

427 This is the second in a series of read-across case studies; this particular study examines a

428 category of similar compounds that do not require (or do not undergo) metabolism to exert a

429 potential adverse human health effect [51]. In vivo oral repeated-dose exposure to n-alkanols

430 gives rise to a set of nonspecific symptoms, including clinical symptoms, haematological values

431 outside the normal range, or whole body effects different from normal. Limiting the category to

432 C5 to $\mathrm{C} 13$ analogues assures that the impact of bioavailability on the toxicokinetic and 
433 toxicodynamic profiles is very limited. Primary alkanols are direct-acting toxicants with a

434 reversible mode of toxic action described as nonpolar narcosis (i.e., unspecific interaction with

435 biological membrane in a manner similar to simple anaesthetics). The main route of exposure for

436 alkanols is oral via rapid gastrointestinal absorption. The majority of an oral dose of any n-

437 alkanol is promptly degraded via simple cellular oxidation; the remainder is eliminated as the

438 glucuronide conjugate.

439 Repeated-dose toxicity test results exhibit qualitative consistency in results between and within

440 species. While protocols vary, results of oral repeated-dose testing exhibit qualitative consistency

441 between and within mammals. Typical findings are only mild changes including decreased body

442 weight, slightly increased liver weight, as well as clinical chemical and haematological changes,

443 but typically without concurrent histopathological effects.

444 Within ToxCast, the n-alkanols are among the "least promiscuous chemical classes"; $<2.74 \%$ of

445 the ToxCast assays showing any activity and none of the active assay being associated with

446 specific bioactivity. Screening with in silico profilers reveals that $\mathrm{n}$-alkanols have no predicted

447 potential of nuclear receptor binding.

448 This is a category read-across (i.e., many-to-one several times). While several analogues have

449 been evaluated experimentally in oral repeated-dose testing schemes, the 90-day oral repeated-

450 dose toxicity data and the NOAELs of $1000 \mathrm{mg} / \mathrm{kg} \mathrm{bw} / \mathrm{d}$ for 1-pentanol and1-hexanol is the

451 conservative prediction. A no systemic toxic conclusion with a NOAEL of $1000 \mathrm{mg} / \mathrm{kg} \mathrm{bw} / \mathrm{d}$ can

452 be read across with confidence to untested n-alkanols in the C5 to C13 category listed in Table 3. 
TWS acknowledges funding by the European Cosmetics Association. KRP, ANR, CLM, SEE

456 and MTDC acknowledge funding from the SEURAT-1 Project, which was funded by the

457 European Community’s Seventh Framework Programme (FP7/2007-2013) under grant

458 agreement number 266835 and Cosmetics Europe. Gratitude is expressed to Dr Richard S.

459 Judson of the U.S. EPA, National Center for Computational Toxicology; Office of Research and

460 Development for his assistance with the interpretation of the ToxCast data.

\section{References}

463 [1] Regulation (EC) No 1223/2009 of the European Parliament and of the Council of 30 464 November 2009 on cosmetic products, replacing Directive 76/768/EC. Off. J. Eur. Union.

$$
\text { L 342: 59-209. }
$$

[2] Cronin, M.T.D., Madden, J.C., Enoch S.J., Roberts, D.W., (Eds.), 2013. Chemical Toxicity Prediction: Category Formation and Read-Across Applications. The Royal Society of Chemistry, Cambridge UK.

469 [3] Teubner, W. and Landsiedel, R., 2015. Read-across for hazard assessment: The ugly duckling in growing up. ATLA 43: 67-71.

471 [4] European Chemicals Agency (ECHA). 2012. Practical Guide 6 - How to report read across and categories [ECHA-10-B-11.1-EN]. 32pp. European Chemicals Agency,

\section{$473 \quad$ Helsinki, Finland.}

474 [5] Przybylak, K.R., Schultz, T.W., Richarz, A.-N., Mellor, C.L., Escher, S.E., and Cronin, M.T.D. 2016. Read-across of 90-day rat oral repeated-dose toxicity: A case study for selected $\beta$-olefinic alcohols. Computational Toxicology (in press). 
[6] Fang, Z., Ionescu, P., Chortkoff, B.S., Kandel, L., Sonner, J., Laster, M.J. and Eger, E.I. 1997. Anesthetic potencies of n-alkanols: Results of additivity and solubility studies suggest a mechanism of action similar to that for conventional inhaled anesthetics. Anesth. Analgesia 84: 1042-1048.

[7] McKim, J.M., Bradbury, S.P. and Niemi, G.J. 1987. Fish acute toxicity syndromes and their use in the QSAR approach to hazard assessment. Environ. Health Perspect. 71: 171-186.

[8] Koleva, Y.K., Cronin, M.T., Madden, J.C. and Schwöbel, J.A. 2011. Modelling acute oral mammalian toxicity. 1. Definition of a quantifiable baseline effect. Toxicol. In Vitro 25: 1281-1293.

[9] Veith, G.D., Petkova, E.P. and Wallace, K.B. 2009. A baseline inhalation toxicity model for narcosis in mammals. SAR QSAR Environ. Res. 20: 567-578.

[10] McCreery, M.J. and Hunt, W.A. 1978. Physico-chemical correlates of alcohol intoxication. Neuropharmacology 17: 451-461.

[11] McKarns, S.C., Hansch, C., Caldwell, W.S., Morgan, W.T., Moore, S.K. and Doolittle, D.J. 1997. Correlations between hydrophobicity of short-chain aliphatic alcohols and their ability to alter plasma membrane integrity. Fundam. Applied Toxicol. 36: 62-70.

[12] Strubelt, O., Deters, M., Pentz, R., Siegers, C.-P. and Younes, M. 1999. The toxic and metabolic effects of 23 aliphatic alcohols in the isolated perfused rat liver. Toxicol. Sci. 49: $133-142$.

[13] Pringle, M.J., Brown, K.B. and Miller, K.W. 1981. Can the lipid theories of anesthesia account for the cutoff in anesthetic potency in homologous series of alcohols? Mol. Pharmacol. 19: 49-55.

[14] Voet, D. and Voet, J.G. 1990. Biochemistry. John Wiley \& Sons, New York. 
[15] Kamil, I.A., Smith, J.N. and Williams, R.T. 1953. Studies in detoxication. 46. The metabolism of aliphatic alcohols. The glucuronic acid conjugation of acyclic aliphatic alcohols. Biochem. J. 53: 129-136.

503 [16] Voskoboinikova, V.B. 1966. Substantiation of the maximum permissible concentration of the flotation reagent IM-68 and its component alcohols (hexyl-, heptyl- and octyl) in water reservoirs. Hyg. Sanit. (GUS) 31: 310-315.

[17] Opdyke, D.L. 1973. Monographs on fragrance raw materials. Food Cosmet. Toxicol. 11: 95-115.

508

[18] Patocka, J. and Kuca, K. 2012. Toxic alcohols: Aliphatic saturated alcohols. Mil. Med. Sci. Lett. (Voj. Zdrav. Listy) 81: 142-163.

510 [19] ECB (European Chemicals Bureau) 2000. IUCLID Dataset, Pentan-1-ol (71-41-0) (2000 CD-ROM edition).

512 [20] Butterworth, K.R., Gaunt, I.F., Heading, C.E., Grasso, P. and Gangolli, S.D. 1976. Short513 term toxicity of n-amylalcohol in rats. Food Cosmet. Toxicol. 16: 203-207.

514 [21] ECHA CHEM A 1-pentanol: http://www.echa.europa.eu/web/guest/registration-dossier/$515 \quad$ /registered-dossier/2115 (accessed 27.01.2016).

516 [22] ITII (International Technical Information Institute) 1988. Toxic and Hazardous Industrial 517 Chemicals Safety Manual. Tokyo, Japan.

518 [23] ECHA CHEM B 1-hexanol: http://www.echa.europa.eu/web/guest/registration-dossier/$519 \quad$ /registered-dossier/13265 (accessed 27.01.2016).

520 [24] Bingham, E., Cohrssen, B., and Powell, C.H. 2001. Patty's Toxicology Volumes 1-9 5th 521 ed. John Wiley \& Sons. New York, N.Y. p. 6:440 
522 [25] Truhaut, R. 1974. Contribution à l'étude toxicologique de l'alcool heptylique. Archives des 523 maladies professionelles de médecine du travail, 35: 501-509.

524 [26] ECH CHEM C 1-heptanol: http://www.echa.europa.eu/web/guest/registration-dossier/$525 \quad$ /registered-dossier/5921/7/1 (accessed 27.01.2016).

526 [27] ECHA CHEM D 1-octanol: http://www.echa.europa.eu/web/guest/registration-dossier/$527 \quad$ /registered-dossier/15210 (accessed 27.01.2016).

528 [28] Lewis, R.J. Sr. (ed) 2004a. Sax's Dangerous Properties of Industrial Materials. 11th $529 \quad$ Edition. Wiley-Interscience, Wiley \& Sons, Inc. Hoboken, NJ. p. 1077.

530 [29] Verschueren, K. 2001. Handbook of Environmental Data on Organic Chemicals. Volumes $531 \quad$ 1-2. 4th ed. John Wiley \& Sons. New York, NY. p. 2164.

532 [30] ECHA CHEM E 1-undecanol; http://www.echa.europa.eu/web/guest/registration-dossier/$533 \quad$ /registered-dossier/2096 (accessed 27.01.2016).

534 [31] ECHA CHEM F1-dodecanol: I http://www.echa.europa.eu/web/guest/registration-dossier/$535 \quad$ /registered-dossier/15424 (accessed 27.01.2016).

536 [32] Organization for Economic Co-Operation and Development (OECD) and Screening 537 Information Datasets (SIDS) 2006. High Production Volume Chemicals 1-Dodecanol (Cas 538 No.: 112-53-83). Processed by United Nations Environmental Program (UNEP). Available 539 from http://www.inchem.org/documents/sids/sids/112538.pdf.

540 [33] Raw Material Data Handbook. 1974. Organic Solvents.1: 114.

541 [34] Organization for Economic Co-Operation and Development (OECD) 2015. Guidance 542 Document on the Reporting of Integrated Approaches to Testing and Assessment (IATA). $543 \quad \mathrm{ENV} / \mathrm{JM} / \mathrm{HA}(2015) 7$. 
544 [35] Schultz, T.W., Amcoff, P., Berggren, E., Gautier, F., Klaric, M., Knight, D. J., Mahony,

545 C., Schwarz, M., White, A. and Cronin, M.T.D. 2015. A strategy for structuring and

546 reporting a read-across prediction of toxicity. Reg. Toxicol. Pharmacol. 72: 586-601.

547 [36] European Chemicals Agency (ECHA) Registered substances. Available from:

548 https://echa.europa.eu/information-on-chemicals/registered-substances.

549 [37] Williams, R.T. 1959. The metabolism of some aliphatic aldehydes, ketones and acids. In:

550 Detoxication mechanisms. The metabolism and detoxication of drugs, toxic substances and

$551 \quad$ other organic compounds, 2nd Ed., London: Chapman \& Hall, Ltd., chapter four, pp. 88-

$552 \quad 113$.

553 [38] Moyes, C.D. and Schulte, P.M. 2006. Principles of Animal Physiology. Pearson Benjamin

$554 \quad$ Cummings, San Francisco. p734.

555 [39] Alifimoff, J., Firestone, L. and Miller, K. 1989. Anaesthetic potencies of primary alkanols:

556 implications for the molecular dimensions of the anaesthetic site. Br. J. Pharmacol. 96: 9-

$557 \quad 16$.

558 [40] Edelfors, S. and Ravn-Jonsen, A. 1990. The effects of alcohols in vitro on the nervous cell

559 membrane measured by changes in the $\left(\mathrm{Ca}_{2}{ }^{+} / \mathrm{Mg}_{2}{ }^{+}\right)$ATPase activity and fluidity of the

560 synaptosomal membrane. Pharmacol. Toxicol. 67: 56-60.

561 [41] He, J., Fu, L., Wang, Y., Li, J.J., Wang, X.H., Su, L.M., Sheng, L.X. and Zhao, Y.H.

562 2014. Investigation on baseline toxicity to rats based on aliphatic compounds and

563 comparison with toxicity to fish: Effect of exposure routes on toxicity. Reg. Toxicol.

564 Pharmacol. 70: 98-106. 
[42] Veith, G.D., Call, D.J. and Brooke, L.T. 1983. Structure-toxicity relationships for the fathead minnow, Pimpehales promelas: narcotic industrial chemicals. Can. J. Fish. Aquat. Sci. 40: 743-748.

[43] Raevsky, O.A., Grigorev, V.Y., Weber, E.E. and Dearden, J.C. 2008. Classification and quantification of the toxicity of chemicals to guppy, fathead minnow and rainbow trout: Part 1. Nonpolar narcosis mode of action. QSAR Comb. Sci. 27: 1274-1281.

[44] Schultz, T.W., Seward-Nagel, J., Foster, K.A. and Tucker, V.A. 2004. Structure-activity relationships for aliphatic alcohols and aquatic toxicity to Tetrahymena. Environ. Toxicol. 19: $1-10$.

[45] Schultz, T.W., Sinks, G.D. and Bearden, A.P. 1998. QSARs in aquatic toxicology: A mechanism of action approach comparing toxic potency to Pimephales promelas, Tetrahymena pyriformis, and Vibrio fischeri. In: Devillers, J. (ed.) Comparative QSAR. Taylor and Francis, London, pp. 52-109.

[46] Benane, S.G., Richard, A.M., Blackman, C.F. and Lytle, C.D. 1993. Quantitative structure-toxicity relationships for a series of primary alcohols in a mammalian viral host cell reactivation assay. In Vitro Toxicol. 6: 267-277.

[47] US EPA ToxCast 2014. US EPA website with access to the ToxCast data. https://www.epa.gov/chemical-research/toxicity-forecasting (accessed 16.06.2016). J., Mansouri, K. Patlewicz, G., Williams, A.J., Little, S.B., Crofton, K.M. and Thomas, R.S. 2016. ToxCast chemical landscape: Paving the road to 21st century toxicology. Chem. Res. Toxicol. 29: 1225-1251. 
[49] Mellor, C.L, Steinmetz, F.P, Cronin, M.T.D. 2016. Using molecular initiating events to develop a structural alert based screening workflow for nuclear receptor ligands associated with hepatic steatosis. Chem. Res. Toxicol. 29: 203-212.

[50] Judson, R.S., Houck, K.A., Kavlock, R.J., Knudsen, T.B., Martin, M.T., Mortensen, H.M., Reif, D.M., Richard, A.M., Rotroff, D.M., Shah, I. and Dix, D.J. 2010. Predictive in vitro screening of environmental chemicals - The ToxCast project. Environ. Health Perspect.118:485-492.

595 [51] Berggren, E., Amcoff, P., Benigni, R., Blackburn, K. Carney, E. Cronin, M., Deluyker, H., 596 Gautier, F., Judson, R.S., Kass, G.E.N., Keller, D., Knight, D., Lilienblum, W., Mahony, 597 C., Rusyn, I., Schultz, T., Schwarz, M., Schüürman, G., White, A., Burton, J., Lostia, A., 598 Munn, S., and Worth, A. 2015. Chemical safety assessment using read-across: How can novel testing methods strengthen evidence base for decision-making? Environ. Health Perspect. 123: 1232-1240.

601 


\section{Supplementary material}

\section{Read-Across of 90-day Rat Oral Repeated-Dose Toxicity: A Case Study for Selected n-Alkanols}

Tables for Assessing Similarity of Analogues and Category Members for Read-Across 
Table 1: Comparison of Substance Identification, Structure and Chemical Classifications

\begin{tabular}{|c|c|c|c|c|c|}
\hline ID & Name & CAS No & SMILES & 2D Structure & Molecular Formula \\
\hline 1 & 1-Pentanol & $71-41-0$ & $\mathrm{CCCCCO}$ & & $\mathrm{C} 5 \mathrm{H} 12 \mathrm{O}$ \\
\hline 2 & 1-Hexanol & $111-27-3$ & $\mathrm{CCCCCCO}$ & & $\mathrm{C} 6 \mathrm{H} 14 \mathrm{O}$ \\
\hline 3 & 1-Heptanol & $111-70-6$ & $\mathrm{CCCCCCCO}$ & & $\mathrm{C} 7 \mathrm{H} 16 \mathrm{O}$ \\
\hline 4 & 1-Octanol & $111-87-5$ & $\mathrm{CCCCCCCCO}$ & & $\mathrm{C} 8 \mathrm{H} 18 \mathrm{O}$ \\
\hline 5 & 1-Nonanol & $143-08-8$ & $\mathrm{CCCCCCCCCO}$ & & $\mathrm{C} 9 \mathrm{H} 20 \mathrm{O}$ \\
\hline 6 & 1-Decanol & $112-30-1$ & СССССССССCO & & $\mathrm{C} 10 \mathrm{H} 22 \mathrm{O}$ \\
\hline 7 & 1-Undecanol & $112-42-5$ & СССССССССССО & & $\mathrm{C} 11 \mathrm{H} 24 \mathrm{O}$ \\
\hline 8 & 1-Dodecanol & $112-53-8$ & ССССССССССССО & & $\mathrm{C} 12 \mathrm{H} 26 \mathrm{O}$ \\
\hline 9 & 1-Tridecanol & $112-70-9$ & СССССССССССССО & & $\mathrm{C} 13 \mathrm{H} 28 \mathrm{O}$ \\
\hline
\end{tabular}


Table 2: Comparison of Physico-Chemical and Molecular Properties ${ }^{1}$

\begin{tabular}{|c|c|c|c|c|c|c|c|c|c|}
\hline ID & Name & $\begin{array}{l}\text { Molecular } \\
\text { Weight }\end{array}$ & $\underset{\text { Kow }^{1 \mathrm{a}}}{\mathbf{L o g}}$ & $\begin{array}{c}\text { Vapour } \\
\text { Pressure } \\
\text { (Pa, 25 deg } \\
\text { C) }{ }^{1 \mathrm{~b}}\end{array}$ & $\begin{array}{c}\text { Density }^{2} \\
\left(\mathrm{~g} / \mathrm{cm}^{3}\right)\end{array}$ & $\begin{array}{l}\text { Melting } \\
\text { Point (deg } \\
\text { C) }\end{array}$ & $\begin{array}{c}\text { Water } \\
\text { Solubility } \\
(\mathrm{mg} / \mathrm{L}, 25 \\
\text { deg C) }\end{array}$ & $\begin{array}{l}\text { Boiling } \\
\text { Point (deg } \\
\text { C) }{ }^{1 \mathrm{~b}}\end{array}$ & $\mathbf{p K a}^{3}$ \\
\hline 1 & 1-Pentanol & 88.15 & $\begin{array}{c}1.33 \\
1.51(\mathrm{M})\end{array}$ & $\begin{array}{c}353 \\
293(\mathrm{M})\end{array}$ & $0.8 \pm 0.1$ & $\begin{array}{c}-49.96 \\
-78.9(\mathrm{M})\end{array}$ & $\begin{array}{c}20890 \\
22000(\mathrm{M})\end{array}$ & $\begin{array}{c}136.95 \\
137.9(\mathrm{M})\end{array}$ & 15.24 \\
\hline 2 & 1-Hexanol & 102.18 & $\begin{array}{c}1.82 \\
2.03(\mathrm{M})\end{array}$ & $\begin{array}{c}117 \\
124(\mathrm{M})\end{array}$ & $0.8 \pm 0.1$ & $\begin{array}{c}-37.86 \\
-44.6(\mathrm{M})\end{array}$ & $\begin{array}{c}6885 \\
5900 / 6260 \\
(\mathrm{M})\end{array}$ & $\begin{array}{c}159.09 \\
157.6(\mathrm{M})\end{array}$ & 15.38 \\
\hline 3 & 1-Heptanol & 116.21 & $\begin{array}{c}2.31 \\
2.62(\mathrm{M})\end{array}$ & $\begin{array}{c}39.8 \\
31.2(\mathrm{M})\end{array}$ & $0.8 \pm 0.1$ & $\begin{array}{c}-26.03 \\
-34(\mathrm{M})\end{array}$ & $\begin{array}{c}1940 \\
1670 / 1800 \\
(\mathrm{M})\end{array}$ & $\begin{array}{c}180.33 \\
176.4(\mathrm{M})\end{array}$ & 15.38 \\
\hline 4 & 1-Octanol & 130.23 & $\begin{array}{c}2.81 \\
3.00(\mathrm{M}) \\
\end{array}$ & $\begin{array}{l}13.2 \\
10.6 \\
\end{array}$ & $0.8 \pm 0.1$ & $\begin{array}{c}-14.46 \\
-15.5(\mathrm{M}) \\
\end{array}$ & $\begin{array}{c}814 \\
540(\mathrm{M}) \\
\end{array}$ & $\begin{array}{c}200.67 \\
195.1(\mathrm{M}) \\
\end{array}$ & 15.27 \\
\hline 5 & 1-Nonanol & 144.26 & $\begin{array}{c}3.30 \\
3.77(\mathrm{M}) \\
\end{array}$ & $\begin{array}{c}4.38 \\
3.03(\mathrm{M}) \\
\end{array}$ & $0.8 \pm 0.1$ & $\begin{array}{l}-3.15 \\
-5(\mathrm{M})\end{array}$ & $\begin{array}{c}156.8 \\
140(\mathrm{M})\end{array}$ & $\begin{array}{c}220.09 \\
213.3(\mathrm{M})\end{array}$ & 15.22 \\
\hline 6 & 1-Decanol & 158.29 & $\begin{array}{c}3.79 \\
4.57(\mathrm{M}) \\
\end{array}$ & $\begin{array}{c}1.45 \\
1.13(\mathrm{M}) \\
\end{array}$ & $0.8 \pm 0.1$ & $\begin{array}{c}7.89 \\
6.9(\mathrm{M}) \\
\end{array}$ & $\begin{array}{c}28.21 \\
37(\mathrm{M}) \\
\end{array}$ & $\begin{array}{c}238.62 \\
231.1(\mathrm{M}) \\
\end{array}$ & 15.21 \\
\hline 7 & 1-Undecanol & 172.31 & 4.28 & $\begin{array}{c}0.68 \\
0.396(\mathrm{M})\end{array}$ & $0.8 \pm 0.1$ & $\begin{array}{c}18.67 \\
19(\mathrm{M})\end{array}$ & 43.04 & $\begin{array}{c}256.24 \\
243(\mathrm{M})\end{array}$ & 15.2 \\
\hline 8 & 1-Dodecanol & 186.34 & $\begin{array}{c}4.77 \\
5.13(\mathrm{M}) \\
\end{array}$ & $\begin{array}{c}0.242 \\
0.113(\mathrm{M}) \\
\end{array}$ & $0.8 \pm 0.1$ & $\begin{array}{c}29.19 \\
24(\mathrm{M}) \\
\end{array}$ & $\begin{array}{l}6.898 \\
4(\mathrm{M}) \\
\end{array}$ & $\begin{array}{c}272.96 \\
259(\mathrm{M}) \\
\end{array}$ & 15.2 \\
\hline 9 & 1-Tridecanol & 200.37 & 5.26 & $\begin{array}{c}0.0316 \\
0.0581(\mathrm{M})\end{array}$ & $0.8 \pm 0.1$ & 0.0316 & 4.533 & $\begin{array}{c}288.77 \\
152(\mathrm{M})\end{array}$ & 15.2 \\
\hline
\end{tabular}

$\mathrm{M}=$ measured value

${ }^{1}$ Values typically derived from EPISuite v4.1, ${ }^{a}$ KOWWIN Program (v1.68), ${ }^{\mathrm{b}}$ MPBPWIN v1.43, ${ }^{\mathrm{c}}$ at $25 \mathrm{deg}$ C; (mg/L) Kow (WSKOW v1.42); ${ }^{2}$ ACD/Lab Percepta Platform - PhysChem Module (from ChemSpider); ${ }^{3}$ Predicted by PERCEPTA; predicted by ACD (Advanced Chemistry Development Inc., Toronto, Canada) 
Table 3: Comparison of Substituents, Functional Groups, and Extended Structural Fragments

\begin{tabular}{|c|c|c|c|c|c|c|}
\hline ID & Name & Key Substituent(s) & $\begin{array}{c}\text { Functional } \\
\text { Group(s) }\end{array}$ & $\begin{array}{c}\text { Extended } \\
\text { Fragment(s) }\end{array}$ & Chemical Class: & $\begin{array}{c}\text { Chemical Sub- } \\
\text { Class: }\end{array}$ \\
\hline 1 & 1-Pentanol & $-\mathrm{OH}$ & $-\mathrm{CH}_{3},-\mathrm{CH}_{2}-$ & - & saturated aliphatic alcohols & straight-chain \\
\hline 2 & 1-Hexanol & $-\mathrm{OH}$ & $-\mathrm{CH}_{3},-\mathrm{CH}_{2-}$ & - & saturated aliphatic alcohols & straight-chain \\
\hline 3 & 1-Heptanol & $-\mathrm{OH}$ & $-\mathrm{CH}_{3},-\mathrm{CH}_{2}-$ & - & saturated aliphatic alcohols & straight-chain \\
\hline 4 & 1-Octanol & $-\mathrm{OH}$ & $-\mathrm{CH}_{3},-\mathrm{CH}_{2}-$ & - & saturated aliphatic alcohols & straight-chain \\
\hline 5 & 1-Nonanol & $-\mathrm{OH}$ & $-\mathrm{CH}_{3},-\mathrm{CH}_{2}-$ & - & saturated aliphatic alcohols & straight-chain \\
\hline 6 & 1-Decanol & $-\mathrm{OH}$ & $-\mathrm{CH}_{3},-\mathrm{CH}_{2}-$ & - & saturated aliphatic alcohols & straight-chain \\
\hline 7 & 1-Undecanol & $-\mathrm{OH}$ & $-\mathrm{CH}_{3},-\mathrm{CH}_{2}-$ & - & saturated aliphatic alcohols & straight-chain \\
\hline 8 & 1-Dodecanol & $-\mathrm{OH}$ & $-\mathrm{CH}_{3},-\mathrm{CH}_{2}-$ & - & saturated aliphatic alcohols & straight-chain \\
\hline 9 & 1-Tridecanol & $-\mathrm{OH}$ & $-\mathrm{CH}_{3},-\mathrm{CH}_{2}-$ & - & saturated aliphatic alcohols & straight-chain \\
\hline
\end{tabular}

Table 4: Comparison of Abiotic Transformation and Toxicokinetics 


\begin{tabular}{|c|c|c|c|c|c|c|}
\hline \multirow[b]{2}{*}{ ID } & \multirow[b]{2}{*}{ Name } & \multirow{2}{*}{$\begin{array}{c}\text { Abiotic } \\
\text { Transformation }\end{array}$} & \multicolumn{4}{|c|}{ Toxicokinetics } \\
\hline & & & $\begin{array}{c}\text { Absorptio } \\
\text { n }\end{array}$ & Bioavailability & half-life & Elimination \\
\hline 1 & 1-Pentanol & & & & & \\
\hline 2 & 1-Hexanol & $\begin{array}{l}\text { Phototransformat } \\
\text { ion in air - half- } \\
\text { life: } 30.8 \mathrm{hrs}^{\mathrm{c}}\end{array}$ & & & & $\begin{array}{l}\text { Rabbit: } 10.3 \% \text { as hexyl } \\
\text { glucuronide }\end{array}$ \\
\hline 3 & 1-Heptanol & $\begin{array}{l}\text { Phototransformat } \\
\text { ion in air - half- } \\
\text { life: } 28.1^{\mathrm{c}}\end{array}$ & & & & $\begin{array}{l}\text { Rabbit: } 5.3 \% \text { as heptyl } \\
\text { glucuronide }^{\mathrm{e}}\end{array}$ \\
\hline 4 & 1-Octanol & $\begin{array}{l}\text { Phototransformat } \\
\text { ion in air - half- } \\
\text { life: } 26.7 \mathrm{hrs}^{\mathrm{d}}\end{array}$ & $\begin{array}{l}\text { orally } \\
\text { rapidly } \\
\text { absorbed }^{\mathrm{a}, \mathrm{b}}\end{array}$ & $>80 \%{ }^{\mathrm{a}, \mathrm{b}}$ & & $\begin{array}{l}\text { mainly as } \mathrm{CO}_{2} \text {, small amount } \\
\text { as n-octyl glucuronide }{ }^{\mathrm{a}, \mathrm{b}} \text {; } \\
\text { Rabbit: } 9.5 \% \text { as octyl } \\
\text { glucuronide }\end{array}$ \\
\hline 5 & 1-Nonanol & & & & & $\begin{array}{l}\text { Rabbit: } 4.1 \% \text { as nonyl } \\
\text { glucuronide }\end{array}$ \\
\hline 6 & 1-Decanol & & & & & $\begin{array}{l}\text { Rabbit: } 3.5 \% \text { as decyl } \\
\text { glucuronide }\end{array}$ \\
\hline 7 & 1-Undecanol & & & & & \\
\hline 8 & 1-Dodecanol & & & & & \\
\hline 9 & 1-Tridecanol & & & & & \\
\hline
\end{tabular}

${ }^{a}$ Williams, R.T. 1959. The metabolism of some aliphatic aldehydes, ketones and acids. In: Detoxication mechanisms. The metabolism and detoxication of drugs, toxic substances and other organic compounds, 2nd Ed., London: Chapman \& Hall, Ltd., chapter four, pp. 88-113; ${ }^{b}$ Opdyke, D.L. 1973. Monographs on fragrance raw materials. Food Cosmet. Toxicol. 11: 95-115; ' Kwok, E.S.C. and Atkinson, R.,1994. Gasphase atmospheric chemistry of dibenzo-pdioxin and dibenzofuran. Environ.Sci.Technol. 28:528-533; ${ }^{\mathrm{d}}$ Atkinson, R. 1994. Gas-phase

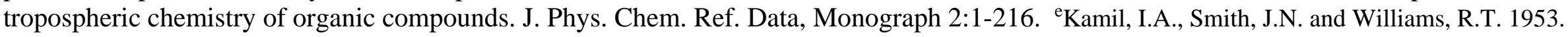
Studies in detoxication. 46. The metabolism of aliphatic alcohols. The glucuronic acid conjugation of acyclic aliphatic alcohols. Biochem. J. 53: 129-136. 
Table 5: Comparison of Potential Metabolic Products

\begin{tabular}{|c|c|c|c|c|c|c|}
\hline \multirow{2}{*}{ ID } & \multirow{2}{*}{ Name } & \multicolumn{2}{|c|}{$\begin{array}{l}\text { Liver metabolism simulator Toolbox } \\
\text { v3.3 }\end{array}$} & \multirow[t]{2}{*}{$\begin{array}{l}\text { MetaPrint2D-React } \\
\text { software }\end{array}$} & \multirow[t]{2}{*}{$\begin{array}{l}\text { SMARTCyp } \\
\text { version } 2.4 .2\end{array}$} & \multirow[t]{2}{*}{ Meteor Nexus } \\
\hline & & Rat liver S9 & Skin metabolism & & & \\
\hline 1 & 1-Pentanol & $\begin{array}{l}\text { Hydroxylation (1) } \\
\text { Oxidation (1) }\end{array}$ & Hydroxylation (2) & $\begin{array}{l}\text { Hydroxylation } \\
\text { Oxidation } \\
\text { Acylation } \\
\text { Dehydroxylation } \\
\text { Methylation } \\
\text { Alkylation } \\
\text { Dealkylation }\end{array}$ & $\begin{array}{l}\text { Possible sites of } \\
\text { metabolism have } \\
\text { been identified }\end{array}$ & $\begin{array}{l}\text { Hydroxylation (3) } \\
\text { Oxidation (1) } \\
\text { beta-Oxidation of } \\
\text { Carboxylic Acids (1) }\end{array}$ \\
\hline 2 & 1-Hexanol & $\begin{array}{l}\text { Hydroxylation (1) } \\
\text { Oxidation (1) }\end{array}$ & Hydroxylation (2) & $\begin{array}{l}\text { Hydroxylation } \\
\text { Oxidation } \\
\text { Acylation } \\
\text { Dehydroxylation } \\
\text { Methylation } \\
\text { Alkylation } \\
\text { Dealkylation } \\
\text { Dehydration } \\
\text { Demethylation }\end{array}$ & $\begin{array}{l}\text { Possible sites of } \\
\text { metabolism have } \\
\text { been identified }\end{array}$ & $\begin{array}{l}\text { Hydroxylation (3) } \\
\text { Oxidation (1) } \\
\text { beta-Oxidation of } \\
\text { Carboxylic Acids (1) }\end{array}$ \\
\hline 3 & 1-Heptanol & $\begin{array}{l}\text { Hydroxylation (1) } \\
\text { Oxidation (1) }\end{array}$ & Hydroxylation (2) & $\begin{array}{l}\text { Hydroxylation } \\
\text { Oxidation } \\
\text { Acylation } \\
\text { Dehydroxylation } \\
\text { Methylation } \\
\text { Alkylation } \\
\text { Dealkylation } \\
\text { Dehydration } \\
\text { Demethylation }\end{array}$ & $\begin{array}{l}\text { Possible sites of } \\
\text { metabolism have } \\
\text { been identified }\end{array}$ & $\begin{array}{l}\text { Hydroxylation (3) } \\
\text { Oxidation (1) }\end{array}$ \\
\hline 4 & 1-Octanol & $\begin{array}{l}\text { Hydroxylation (2) } \\
\text { Oxidation (1) }\end{array}$ & Hydroxylation (2) & $\begin{array}{l}\text { Hydroxylation } \\
\text { Oxidation } \\
\text { Acylation } \\
\text { Dehydroxylation } \\
\text { Methylation } \\
\text { Alkylation }\end{array}$ & $\begin{array}{l}\text { Possible sites of } \\
\text { metabolism have } \\
\text { been identified }\end{array}$ & $\begin{array}{l}\text { Hydroxylation (3) } \\
\text { Oxidation (1) }\end{array}$ \\
\hline
\end{tabular}




\begin{tabular}{|c|c|c|c|c|c|c|}
\hline \multirow{2}{*}{ ID } & \multirow{2}{*}{ Name } & \multicolumn{2}{|c|}{$\begin{array}{l}\text { Liver metabolism simulator Toolbox } \\
\text { v3.3 }\end{array}$} & \multirow[t]{2}{*}{$\begin{array}{l}\text { MetaPrint2D-React } \\
\text { software }\end{array}$} & \multirow[t]{2}{*}{$\begin{array}{l}\text { SMARTCyp } \\
\text { version } 2.4 .2\end{array}$} & \multirow[t]{2}{*}{ Meteor Nexus } \\
\hline & & Rat liver S9 & Skin metabolism & & & \\
\hline & & & & $\begin{array}{l}\text { Dealkylation } \\
\text { Dehydration } \\
\text { Demethylation }\end{array}$ & & \\
\hline 5 & 1-Nonanol & $\begin{array}{l}\text { Hydroxylation (2) } \\
\text { Oxidation (1) }\end{array}$ & Hydroxylation (2) & $\begin{array}{l}\text { Hydroxylation } \\
\text { Oxidation } \\
\text { Acylation } \\
\text { Dehydroxylation } \\
\text { Methylation } \\
\text { Alkylation } \\
\text { Dealkylation } \\
\text { Dehydration } \\
\text { Demethylation } \\
\end{array}$ & $\begin{array}{l}\text { Possible sites of } \\
\text { metabolism have } \\
\text { been identified }\end{array}$ & $\begin{array}{l}\text { Hydroxylation (3) } \\
\text { Oxidation (1) }\end{array}$ \\
\hline 6 & 1-Decanol & $\begin{array}{l}\text { Hydroxylation (2) } \\
\text { Oxidation (1) }\end{array}$ & Hydroxylation (2) & $\begin{array}{l}\text { Hydroxylation } \\
\text { Oxidation } \\
\text { Acylation } \\
\text { Dehydroxylation } \\
\text { Methylation } \\
\text { Alkylation } \\
\text { Dealkylation } \\
\text { Dehydration } \\
\text { Demethylation } \\
\end{array}$ & $\begin{array}{l}\text { Possible sites of } \\
\text { metabolism have } \\
\text { been identified }\end{array}$ & $\begin{array}{l}\text { Hydroxylation (3) } \\
\text { Oxidation (1) }\end{array}$ \\
\hline 7 & 1-Undecanol & $\begin{array}{l}\text { Hydroxylation (2) } \\
\text { Oxidation (1) }\end{array}$ & Hydroxylation (2) & $\begin{array}{l}\text { Hydroxylation } \\
\text { Oxidation } \\
\text { Acylation } \\
\text { Dehydroxylation } \\
\text { Methylation } \\
\text { Alkylation } \\
\text { Dealkylation } \\
\text { Dehydration } \\
\text { Demethylation } \\
\end{array}$ & $\begin{array}{l}\text { Possible sites of } \\
\text { metabolism have } \\
\text { been identified }\end{array}$ & $\begin{array}{l}\text { Hydroxylation (3) } \\
\text { Oxidation (1) }\end{array}$ \\
\hline
\end{tabular}




\begin{tabular}{|c|c|c|c|c|c|c|}
\hline \multirow[t]{2}{*}{ ID } & \multirow{2}{*}{ Name } & \multicolumn{2}{|c|}{$\begin{array}{l}\text { Liver metabolism simulator Toolbox } \\
\text { v3.3 }\end{array}$} & \multirow[t]{2}{*}{$\begin{array}{l}\text { MetaPrint2D-React } \\
\text { software }\end{array}$} & \multirow[t]{2}{*}{$\begin{array}{l}\text { SMARTCyp } \\
\text { version } 2.4 .2\end{array}$} & \multirow[t]{2}{*}{ Meteor Nexus } \\
\hline & & Rat liver S9 & Skin metabolism & & & \\
\hline 8 & 1-Dodecanol & $\begin{array}{l}\text { Hydroxylation (2) } \\
\text { Oxidation (1) }\end{array}$ & Hydroxylation (2) & $\begin{array}{l}\text { Hydroxylation } \\
\text { Oxidation } \\
\text { Acylation } \\
\text { Dehydroxylation } \\
\text { Methylation } \\
\text { Alkylation } \\
\text { Dealkylation } \\
\text { Dehydration } \\
\text { Demethylation }\end{array}$ & $\begin{array}{l}\text { Possible sites of } \\
\text { metabolism have } \\
\text { been identified }\end{array}$ & $\begin{array}{l}\text { Hydroxylation (3) } \\
\text { Oxidation (1) }\end{array}$ \\
\hline 9 & 1-Tridecanol & $\begin{array}{l}\text { Hydroxylation (2) } \\
\text { Oxidation (1) }\end{array}$ & Hydroxylation (2) & $\begin{array}{l}\text { Hydroxylation } \\
\text { Oxidation } \\
\text { Acylation } \\
\text { Dehydroxylation } \\
\text { Methylation } \\
\text { Alkylation } \\
\text { Dealkylation } \\
\text { Dehydration } \\
\text { Demethylation }\end{array}$ & $\begin{array}{l}\text { Possible sites of } \\
\text { metabolism have } \\
\text { been identified }\end{array}$ & $\begin{array}{l}\text { Hydroxylation (3) } \\
\text { Oxidation (1) }\end{array}$ \\
\hline
\end{tabular}

() - The number of metabolites for specific transformation. 
Table 6: Comparison of Toxicophores

\begin{tabular}{|l|l|l|l|l|c|c|}
\hline $\mathbf{I D}$ & \multicolumn{1}{|c|}{ Name } & Toxicophores & $\begin{array}{c}\text { DNA binding by } \\
\text { OECD }\end{array}$ & $\begin{array}{c}\text { Protein } \\
\text { binding by } \\
\text { OECD }^{\mathbf{1}}\end{array}$ & $\begin{array}{c}\text { Nuclear receptor } \\
\text { binding }^{\mathbf{2}}\end{array}$ & $\begin{array}{c}\text { Liver\& } \\
\text { Mitochondria } \\
\text { toxicity }\end{array}$ \\
\hline $\mathbf{1}$ & 1-Pentanol & Cramer Class I & No alert & Inactive & No alert \\
\hline $\mathbf{2}$ & 1-Hexanol & Cramer Class I & No alert & No alert & Inactive & No alert \\
\hline $\mathbf{3}$ & 1-Heptanol & Cramer Class I & No alert & No alert & Inactive & No alert \\
\hline $\mathbf{4}$ & 1-Octanol & Cramer Class I & No alert & No alert & Inactive & No alert \\
\hline $\mathbf{5}$ & 1-Nonanol & Cramer Class I & No alert & No alert & Inactive & No alert \\
\hline $\mathbf{6}$ & 1-Decanol & Cramer Class I & No alert & No alert & Inactive & No alert \\
\hline $\mathbf{7}$ & 1-Undecanol & Cramer Class I & No alert & No alert & Inactive & No alert \\
\hline $\mathbf{8}$ & 1-Dodecanol & Cramer Class I & No alert & No alert & Inactive & No alert \\
\hline $\mathbf{9}$ & 1-Tridecanol & Cramer Class I & No alert & No alert & Inactive & No alert \\
\hline
\end{tabular}

${ }^{1}$ OECD QSAR Toolbox $3.3 .{ }^{2}$ COSMOS profilers available via COSMOS space: http://cosmosspace.cosmostox.eu 
Table 7: Comparison of Mechanistic Plausibility and Adverse Outcome Pathway-Related Event Data

\begin{tabular}{|c|c|c|c|c|c|c|c|}
\hline ID & Name & $\begin{array}{l}\text { Mechanistic } \\
\text { Plausibility }\end{array}$ & $\begin{array}{c}\text { Adverse } \\
\text { Outcome } \\
\text { Pathway or } \\
\text { Mode of Toxic } \\
\text { Action: }\end{array}$ & $\begin{array}{l}\text { Molecular } \\
\text { Initiating } \\
\text { Event: }\end{array}$ & $\begin{array}{c}\text { Key Event } 1 \\
\text { etc.: }\end{array}$ & $\begin{array}{c}\text { Key Event } \\
\text { Relationship } 1 \\
\text { etc.: }\end{array}$ & $\begin{array}{l}\text { Other } \\
\text { Mechanistically- } \\
\text { Relevant Events }\end{array}$ \\
\hline 1 & 1-Pentanol & & $\begin{array}{l}\text { narcosis - } \\
\text { depressant } \\
\text { anesthesia }\end{array}$ & $\begin{array}{l}\text { unspecific } \\
\text { interactions } \\
\text { with biological } \\
\text { membranes }\end{array}$ & & & \\
\hline 2 & 1-Hexanol & & $\begin{array}{l}\text { narcosis - } \\
\text { depressant } \\
\text { anesthesia }\end{array}$ & $\begin{array}{l}\text { unspecific } \\
\text { interactions } \\
\text { with biological } \\
\text { membranes }\end{array}$ & & & CNS depression \\
\hline 3 & 1-Heptanol & & $\begin{array}{l}\text { narcosis - } \\
\text { depressant } \\
\text { anesthesia }\end{array}$ & $\begin{array}{l}\text { unspecific } \\
\text { interactions } \\
\text { with biological } \\
\text { membranes }\end{array}$ & & & \\
\hline 4 & 1-Octanol & & $\begin{array}{l}\text { narcosis - } \\
\text { depressant } \\
\text { anesthesia }\end{array}$ & $\begin{array}{l}\text { unspecific } \\
\text { interactions } \\
\text { with biological } \\
\text { membranes }\end{array}$ & & & $\begin{array}{c}\text { CNS depression } \\
\text { biphasic effect } \\
\text { on the ATPase } \\
\text { activity }\end{array}$ \\
\hline 5 & 1-Nonanol & & $\begin{array}{l}\text { narcosis - } \\
\text { depressant } \\
\text { anesthesia }\end{array}$ & $\begin{array}{l}\text { unspecific } \\
\text { interactions } \\
\text { with biological } \\
\text { membranes }\end{array}$ & & & \\
\hline 6 & 1-Decanol & & $\begin{array}{l}\text { narcosis - } \\
\text { depressant } \\
\text { anesthesia }\end{array}$ & $\begin{array}{l}\text { unspecific } \\
\text { interactions } \\
\text { with biological } \\
\text { membranes }\end{array}$ & & & $\begin{array}{c}\text { biphasic effect } \\
\text { on the ATPase } \\
\text { activity }\end{array}$ \\
\hline 7 & 1-Undecanol & & $\begin{array}{l}\text { narcosis - } \\
\text { depressant } \\
\text { anesthesia }\end{array}$ & $\begin{array}{l}\text { unspecific } \\
\text { interactions } \\
\text { with biological } \\
\text { membranes }\end{array}$ & & & \\
\hline
\end{tabular}




\begin{tabular}{|c|c|c|c|c|c|c|c|}
\hline ID & Name & $\begin{array}{l}\text { Mechanistic } \\
\text { Plausibility }\end{array}$ & $\begin{array}{c}\text { Adverse } \\
\text { Outcome } \\
\text { Pathway or } \\
\text { Mode of Toxic } \\
\text { Action: } \\
\end{array}$ & $\begin{array}{l}\text { Molecular } \\
\text { Initiating } \\
\text { Event: }\end{array}$ & $\begin{array}{c}\text { Key Event } 1 \\
\text { etc.: }\end{array}$ & $\begin{array}{c}\text { Key Event } \\
\text { Relationship } 1 \\
\text { etc.: }\end{array}$ & $\begin{array}{l}\text { Other } \\
\text { Mechanistically- } \\
\text { Relevant Events }\end{array}$ \\
\hline 8 & 1-Dodecanol & & $\begin{array}{l}\text { narcosis - } \\
\text { depressant } \\
\text { anesthesia }\end{array}$ & $\begin{array}{l}\text { unspecific } \\
\text { interactions } \\
\text { with biological } \\
\text { membranes }\end{array}$ & & & $\begin{array}{l}\text { stimulation of the } \\
\text { ATPase activity }\end{array}$ \\
\hline 9 & 1-Tridecanol & & $\begin{array}{l}\text { narcosis - } \\
\text { depressant } \\
\text { anesthesia }\end{array}$ & $\begin{array}{l}\text { unspecific } \\
\text { interactions } \\
\text { with biological } \\
\text { membranes }\end{array}$ & & & \\
\hline
\end{tabular}


Table 8: Comparison of Toxicologically Relevant In Vivo, In Vitro and Ex Vivo Data

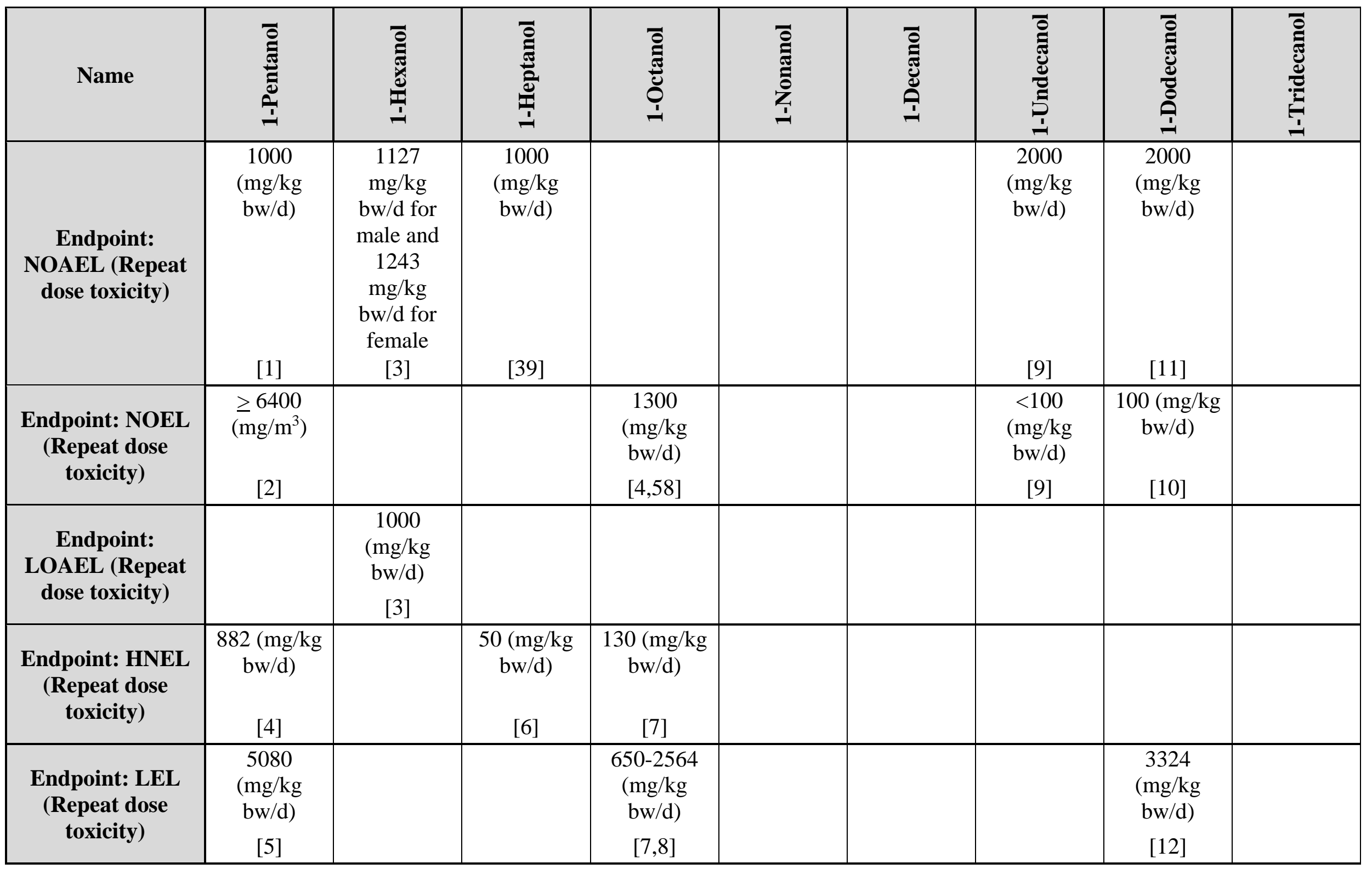




\begin{tabular}{|c|c|c|c|c|c|c|c|c|c|}
\hline Name & 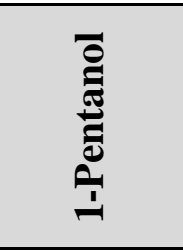 & & 竞 & 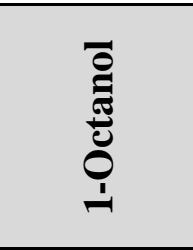 & 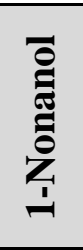 & 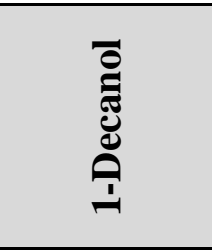 & 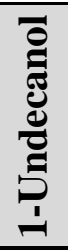 & 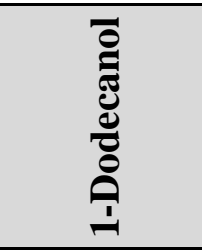 & 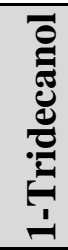 \\
\hline $\begin{array}{l}\text { Endpoint: LOEL } \\
\text { (Repeat dose } \\
\text { toxicity) }\end{array}$ & & & & & & & & $\begin{array}{c}100-2000 \\
(\mathrm{mg} / \mathrm{kg} / \mathrm{d}) \\
{[13]} \\
\end{array}$ & \\
\hline $\begin{array}{c}\text { Endpoint: } \\
\text { NOAEL } \\
\text { (Reproductive } \\
\text { toxicity) } \\
\end{array}$ & $\begin{array}{c}1000 \\
(\mathrm{mg} / \mathrm{kg} / \mathrm{d} \\
{[1]} \\
\end{array}$ & & & & & & & & \\
\hline $\begin{array}{c}\text { Endpoint: } \\
\text { NOAEL } \\
\text { (Teratogenicity) }\end{array}$ & & $\begin{array}{c}370-1240 \\
(\mathrm{mg} / \mathrm{kg} / \mathrm{d}) \\
{[3]}\end{array}$ & & $\begin{array}{c}1300 \\
(\mathrm{mg} / \mathrm{kg} / \mathrm{d}) \\
{[16]}\end{array}$ & & & & & \\
\hline $\begin{array}{c}\text { Endpoint: } \\
\text { NOAEC } \\
\text { (Teratogenicity) }\end{array}$ & $\begin{array}{c}14(\mathrm{mg} / \mathrm{L} \\
\text { air) } \\
\\
{[15]}\end{array}$ & $\begin{array}{c}3.5(\mathrm{mg} / \mathrm{L} \\
\text { air }) \\
{[3]}\end{array}$ & & & & $\begin{array}{c}>100(\mathrm{mg} / \mathrm{L} \\
\text { air }) \\
{[61]}\end{array}$ & & & \\
\hline $\begin{array}{l}\text { Endpoint: } \\
\text { LOAEL } \\
\text { (Maternal } \\
\text { toxicity) } \\
\end{array}$ & & & & $\begin{array}{c}130 \\
(\mathrm{mg} / \mathrm{kg} / \mathrm{d}) \\
{[17]} \\
\end{array}$ & & $\begin{array}{c}130 \\
(\mathrm{mg} / \mathrm{kg} / \mathrm{d}) \\
{[61]}\end{array}$ & & & \\
\hline $\begin{array}{l}\text { Endpoint: } \\
\text { NOAEC } \\
\text { (Maternal } \\
\text { toxicity) }\end{array}$ & & & & $\begin{array}{c}>0.4 \\
(\mathrm{mg} / \mathrm{L}) \\
\\
{[16]}\end{array}$ & & & & & \\
\hline
\end{tabular}




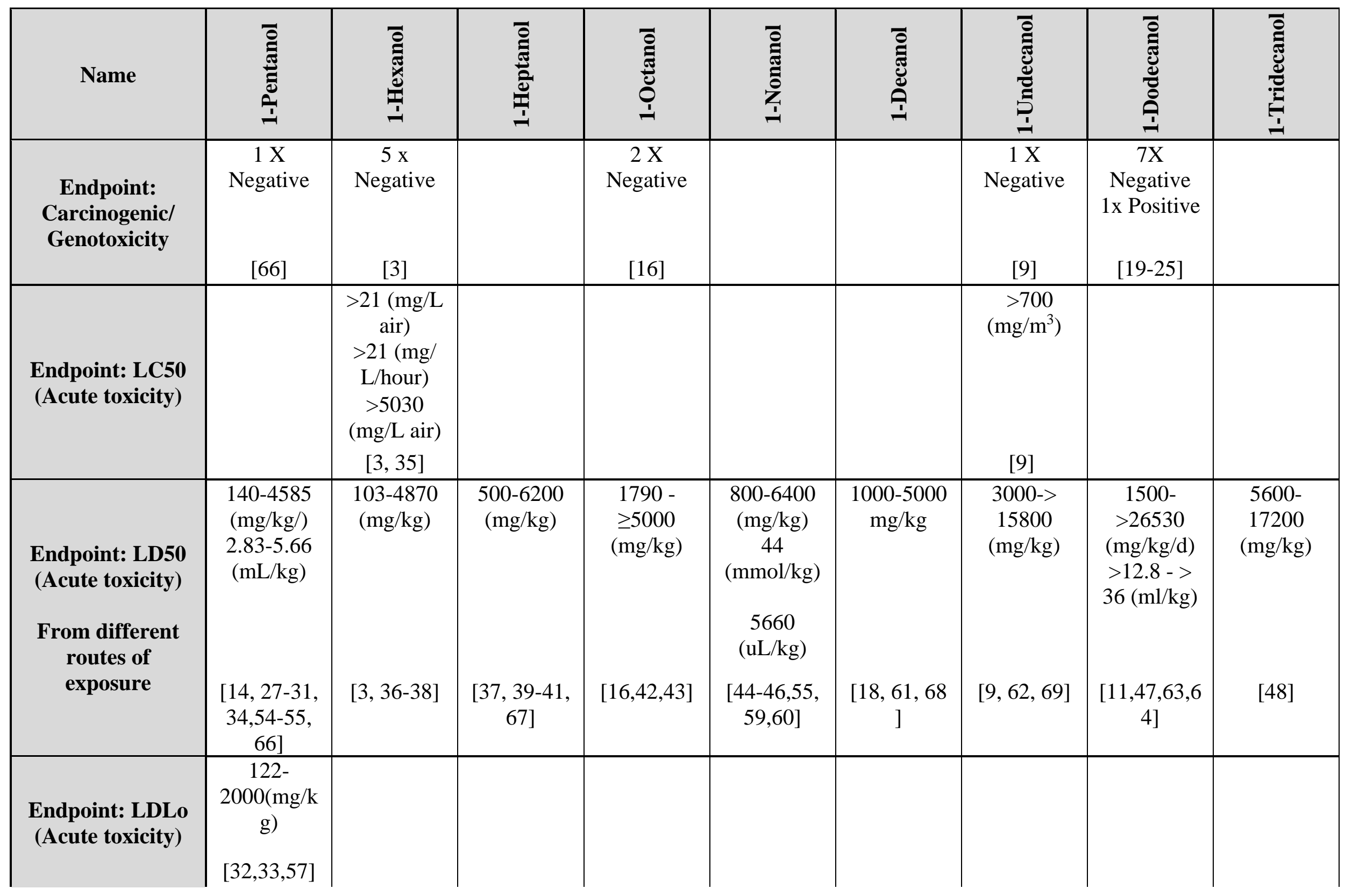




\begin{tabular}{|c|c|c|c|c|c|c|c|c|c|}
\hline Name & 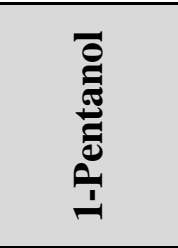 & 总 & & 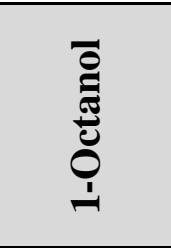 & 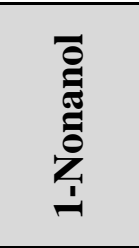 & & 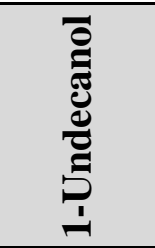 & 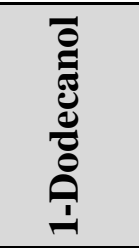 & 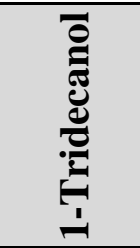 \\
\hline $\begin{array}{l}\text { Endpoint: } \\
\text { Genotoxicity } \\
\text { (AMES, } \\
\text { Chromosomal } \\
\text { abrration, gene } \\
\text { mutation) }\end{array}$ & $\begin{array}{c}2 \mathrm{x} \\
\text { Negative } \\
{[52,57]}\end{array}$ & $\begin{array}{c}1 \mathrm{x} \\
\text { Negative }\end{array}$ & $\begin{array}{c}1 \mathrm{x} \\
\text { Negative } \\
{[39]}\end{array}$ & $\begin{array}{c}1 \mathrm{x} \\
\text { Negative } \\
{[50]}\end{array}$ & & $\begin{array}{c}2 \mathrm{x} \\
\text { Negative } \\
{[26,51]}\end{array}$ & & & \\
\hline $\begin{array}{c}\text { Toxcast overview } \\
{[53]}\end{array}$ & - & $\begin{array}{l}250(1 \\
\text { active })\end{array}$ & $\begin{array}{l}250(10 \\
\text { active })\end{array}$ & $\begin{array}{l}602(0 \\
\text { active })\end{array}$ & $\begin{array}{l}150(4 \\
\text { active })\end{array}$ & $\begin{array}{l}257(15 \\
\text { active })\end{array}$ & $\begin{array}{l}602(25 \\
\text { active })\end{array}$ & $\begin{array}{l}602(3 \\
\text { active })\end{array}$ & $\begin{array}{l}602(30 \\
\text { active })\end{array}$ \\
\hline
\end{tabular}

\section{$\underline{\text { References for Table } 8}$}

[1] Butterworth, K.R., Gaunt, F., Heading, C.E., Grassot, P. and Gangolli, S.D. 1978. Short-term toxicity of n-amyl alcohol in rats. Fd. Cosmet. Toxicol. 16: 203-207.

[2] ECHA CHEM for 1-pentanol: http://www.echa.europa.eu/web/guest/registration-dossier/-/registered-dossier/2115

[3] ECHA CHEM for 1-hexanol: http://www.echa.europa.eu/web/guest/registration-dossier/-/registered-dossier/13265

[4] Ray S.D, Mehendale H.D 1990. Potentiation of CCl4 and CHCl3 hepatotoxicity and lethality by various alcohols Fundam. Appl. Toxicol. 15(3): 429-440.

[5] Vaquera, J., Vaquera, A. and Girbes, T. 2002. Effects of chronic administration of either ethanol or pentanol on rat duodenum morphology. Histol. Histopathol. 17:199-203.

[6] US FDA CFSAN PAFA 1; Uch Zap Mosk Nauchn Issled Inst Gigieny 9: 40-46.

[7] US FDA CFSAN PAFA 27; Food. Chem. Toxicol. 35:489-500.

[8] US FDA CFSAN PAFA 18; Acta Pathol. Jpn. 41: 405-413.

[9] ECHA CHEM for 1-undecanol; http://echa.europa.eu/registration-dossier/-/registered-dossier/2096

[10] Hansen, E. 1992. Combined Repeat Dose and Reproductive/Developmental Toxicity Screening Test on 1-Dodecanol in Rats. Institute of Toxicology, Danish National Food Agency, IT 921105.

[11] ECHA CHEM for 1-dodecanol; http://www.echa.europa.eu/web/guest/registration-dossier/-/registered-dossier/15424; 
[12] Wakabayashi, T., Adachi, K. and Popinigis, J. 1991. Effects of Alkyl Alcohols and Related Chemicals on Rat Liver Structure and Function. Acta. Pathol. Jpn. 41: 405-413.

[13] Danish National Food Agency 1992. Combined repeated dose and reproductive/developmental toxicity screening test in rats. Danish National Food Agency, IT 9211105

[14] Toxicity Testing Reports of Environmental (Ministry of Health and Welfare, Japan) 1997. Rep Dose Tox Fraunhofer

[15] Nelson B.K, Brightwell S.W, Khan A, Krieg E.F and Hoberman A.M 1989. Developmental Toxicology Evaluation of 1-Pentanol, 1Hexanol, and 2-Ethyl-1-Hexanol Administered by Inhalation to Rats. J Am Col Toxicol 8(2): 405-410.

[16] ECHA CHEM search for 1-octanol: http://www.echa.europa.eu/web/guest/registration-dossier/-/registered-dossier/15210

[17] Nelson, B.K, Brightwell, W.W., Khan, A., Krieg, E.F. and Hoberman, A.M. 1990. Developmental toxicology assessment of 1-Octanol 1-Nonanol and 1-Decanol administered by inhalation to rats. J. Amer. College Toxicol 9(1): 93-97.

[18] Klimisch, H.-J. and Hellwig, J. 1995. Studies on the Prenatal Toxicity of 3-Methyl-1-butanol and 2-Methyl-1-propanol in Rats and Rabbits Following Inhalation Exposure. Fund. Appl. Toxicol. 27(1): 77-89.

[19] Banduhn, N. 1992. Henkel KGaA, Toxikologie, 1-dodecanol (Lorol C12-99), Micronucleus Test in vivo in Bone Marrow Cells of the Mouse, Report, May 1992.

[20] Barilyak, I.R. and Kozachuk, S.Y. 1988. Studies in cytogenetic action of some monohydric alcohols on the rat bone marrow cells (Russian). Tsitol. Genet. 22: 49-52.

[21] Stoner, G.D., Shimkin, M.B., Kniazeff, A.J., Weisburger, J.H., Weisburger, E.K. and Gori, G.B. 1973. Test for carcinogenicity of food additives and chemotherapeutic agents by pulmonary tumor response in strain A mice. Cancer Research, 33: 3069-3085.

[22] van Duuren, B.L and Goldschmidt, B.M. 1976. Cocarcinogenic and tumor-promoting agents in tobacco carcinogenesis. J. Nat. Cancer Inst. 56: 1237-1242.

[23] Sice, J. 1966. Tumor-promoting activity of n-alkanes and 1-alkanols. 1966. Toxicol. Applied Pharmacol. 9: 70-73.

[24] Bingham, E.L. and Falk, H.L. 1969. Environmental carcinogens: the modifying effect of cocarcinogens on the threshold response. Arch. Environ. Health 19: 779-783.

[25] Ando, K., Kodama, K., Kato, A., Tamura, G. and Arima, K. 1972. Antitumor activity of glyceryl ethers. Cancer Research 32: $125-129$.

[26] Ccris database, http://toxnet.nlm.nih.gov/newtoxnet/ccris.htm

[27] Jenner, P.M., Hagen, E.C., Taylor, J.M., Cook, E.L. and Fitzhugh, O.G. 1964. Food flavourings and compounds of related structure. Acute oral toxicity. Fd. Cosmet. Toxicol. 2: 327-343.

[28] ChemIDplus search results, http://chem.sis.nlm.nih.gov/chemidplus/rn/64-17-5. Original reference given; EHP, Environmental Health Perspectives.1985. Vol. 61, Pg. 321.

[29] National Technical Information Service. Vol. OTS0534716, http://www.ntis.gov/about/

[30] ECHA CHEM registered substances, http://echa.europa.eu/information-on-chemicals/registered-substances,Study report 1973 
[31] ECHA CHEM registered substances, http://echa.europa.eu/information-on-chemicals/registered-substances,Study report 1978

[32] ChemIDplus search, http://chem.sis.nlm.nih.gov/chemidplus/rn/100-51-6. Original reference cited; Journal of Pharmacology and Experimental Therapeutics. Vol. 16, Pg. 1, 1920.

[33] ChemIDplus search, http://chem.sis.nlm.nih.gov/chemidplus/rn/71-41-0. Original reference cited: Comptes Rendus Hebdomadaires des Seances, Academie des Sciences. 1975. Vol. 81, Pg. 192.

[34] Chvapil, M., Zahradnik, R. and Cmuchalova, B. 1962. Influence of alcohols and potassium salts of xanthogenic acids on vari. Arch Int Pharmacodyn Ther. 1962 Feb lous biological objects; 135: 330.

[35] European Chemicals Bureau; IUCLID Dataset, 1-Hexanol (111-27-3) (2000 CD-ROM edition). Available from, as of April 20, 2006: http://esis.jrc.ec.europa.eu/

[36] Lewis, R.J. Sr. 1955. Sax's Dangerous Properties of Industrial Materials. 11th Edition. Wiley-Interscience, Wiley \& Sons, Inc. Hoboken, NJ. 2004.

[37] Bingham, E., Cohrssen, B. and Powell, C.H. 2001. Patty's Toxicology Volumes 1-9 5th ed. John Wiley \& Sons. New York, N.Y. (2001) p. 6-440.

[38] ITII (1988). Toxic and Hazardous Industrial Chemicals Safety Manual. Tokyo, Japan: The International Technical Information Institute, p. 267.

[39] ECHA CHEM for 1-heptanol: http://www.echa.europa.eu/web/guest/registration-dossier/-/registered-dossier/5921/7/1

[40] US FDA CFSAN PAFA 2; Gig Sanit 31: 310-316.

[41] US FDA CFSAN PAFA 18; Chemosphere 36: 1475-1483.

[42] US FDA CFSAN PAFA 1; Gig Sanit 31:310-316.

[43] US FDA CFSAN PAFA 9; Fd. Cosmet. Toxicol. 11: 101.

[44] Opdyke, D.L.J. 1973. Monographs on fragrance raw materials: Acetate C-9. Fd. Cosmet. Toxicol. 11: 95.

[45] Izmerov, N.F., Sanotsky, I.V. and Sidorov, K.K. 1982.Toxicometric Parameters of Industrial Toxic Chemicals Under Single Exposure. Moscow, Centre of International Projects, GKNT, Pg. 94.

[46] Hau, K.M., Connell, D.W. and Richardson, B.J. 1999. Mechanism of acute inhalation toxicity of alkanes and aliphatic alcohols. Environ. Toxicol. Pharmacol. 7: 159-167.

[47] Lewis, R.J. 1967. Food Additives Handbook. Medizin und Ernaehrung. Vol. 8, p244.

[48] Raw Material Data Handbook 1974. Vol.1: Organic Solvents. p114.

[49] ChemIDplus search, http://chem.sis.nlm.nih.gov/chemidplus/rn/137-32-6. Original reference quoted; Journal of Industrial Hygiene and Toxicology. 1945. Vol. 27, Pg. 1

[50] Edelfors, S.and Ravn-Jonsen, A. 1990. The effects of alcohols in vitro on the nervous cell membrane measured by changes in the $(\mathrm{Ca} 2+/ \mathrm{Mg} 2+)$ ATPase activity membrane fluidity. Pharmacol. Toxicol. 67: 56-60. 
[51] Kreja, L. and Seidel, H.-J. 2002. Evaluation of the genotoxic potential of some microbial volatile organic compounds (MVOC) with the comet assay, the micronucleus assay and the HPRT gene mutation assay. Mut. Res. 513: 143-150.

[52] Nakajima, D., Rhii, R., Kageyama, S., Onji, Y., Mineki, S., Morooka, N., Takatori, K. and Goto, S. 2006. Genotoxicity of microbial volatile organic compounds. J. Health Sci. 5: 148-153.

[53] Toxcast ${ }^{\mathrm{TM}}$ data, Provider the USEPA; http://www.epa.gov/ncct/toxcast/data.html

[54] ChemIDPlus search. Original reference quoted: Gigiena i Sanitariya. For English translation, see HYSAAV. 1970 Vol.35, p 88.

[55] ChemIDPlus search. Original reference quoted: Gigiena i Sanitariya. For English translation, see HYSAAV. 1986. Vol.51, p61.

[56] ChemIDPlus search. Original reference quoted: Archives Internationales de Pharmacodynamie et de Therapie.1935. Vol. 50, p296.

[57] ECHA. Study report 1986. http://apps.echa.europa.eu/registered/data/dossiers/DISS-9d8a5727-6a82-2e4a-e044-00144f67d249/AGGR0517495b-7701-4b59-bb0c-32d003c0f680_DISS-9d8a5727-6a82-2e4a-e044-00144f67d249.html\#AGGR-0517495b-7701-4b59-bb0c$32 \mathrm{~d} 003 \mathrm{c} 0 \mathrm{f} 680$

[58] Hellwig, J., and Jäckh, R. 1997. Differential prenatal toxicity of one straight-chain and five branched-chain primary alcohols in rats. Food Chem. Toxicol. 35: 489-500.

[59] Opdyke, D.L.J. 1973. Monographs on fragrance raw materials: Alcohol C-8. Fd. Cosmet. Toxicol. 11:103-104.

[60] Patty's Industrial Hygiene and Toxicology 3rd rev. 1982. ed., Clayton, G.D., and F.E. Clayton, eds., New York, John Wiley \& Sons, Inc., 1978-82. Vol. 3 originally pub. in 1979; pub. as 2n rev. ed. in 1985.Vol. 2C, p4628.

[61] ECHA CHEM for 1-decanol: http://www.echa.europa.eu/web/guest/registration-dossier/-/registered-dossier/15951/1

[62] US FDA CFSAN PAFA 1; Fd. Cosmet. Toxicol. 16: 641.

[63] Patty's Industrial Hygiene and Toxicology. Vol. II, part D. Clayton, G. D. and Clayton, F. E. (eds.). John Wiley \& Sons Inc. New York. Chapter 55.

[64] "Alcohols," Patty's Industrial Hygiene and Toxicology, 3rd. Ed., Vol. 2C, 1982. Clayton, G., et. al., ed., John Wiley \& Sons, New York, p. 4632-4633.

[65] Stoner, G. D., Shimkin, M. B., Kniazeff, A.J., Weisburger, J.H, Weisburger, E. K. and Gori, G.B. 1973.Test for carcinogenicity of food additives and chemotherapeutic agents by the pulmonary tumor response in strain A mice. Cancer Res. 33: 3069-3085.

[66] European Chemicals Bureau; IUCLID Dataset, Pentan-1-ol (71-41-0) (2000 CD-ROM edition.

[67] Truhaut, R. 1974. Contribution à l'étude toxicologique de l'alcool heptylique. Archives des maladies professionelles de médecine du travail, 35: 501-509.

[68] Lewis, R.J. Sr. (ed) 2004. Sax's Dangerous Properties of Industrial Materials. 11th Edition. Wiley-Interscience, Wiley \& Sons, Inc. Hoboken, NJ. p. 1077.

[69] Verschueren, K. 2001. Handbook of Environmental Data on Organic Chemicals. Volumes 1-2. 4th ed. John Wiley \& Sons. New York, NY.p. 2164. 